\title{
CD1d-Restricted NKT Cells: An Interstrain Comparison ${ }^{1}$
}

\author{
Kirsten J. L. Hammond,* Daniel G. Pellicci,* Lynn D. Poulton, ${ }^{\dagger}$ Olga V. Naidenko, \\ Anthony A. Scalzo, ${ }^{\S}$ Alan G. Baxter, ${ }^{\dagger}$ and Dale I. Godfrey ${ }^{2 *}$
}

CD1d-restricted V $\alpha 14-J \alpha 281$ invariant $\alpha \beta T_{C R}{ }^{+}(\mathrm{NKT})$ cells are well defined in the C57BL/6 mouse strain, but they remain poorly characterized in non-NK1.1-expressing strains. Surrogate markers for NKT cells such as $\alpha \beta \mathrm{TCR}^{+} \mathrm{CD4}^{-} \mathrm{CD8}^{-}$and $\mathrm{DX}^{+} \mathrm{CD3}^{+}$have been used in many studies, although their effectiveness in defining this lineage remains to be verified. Here, we compare NKT cells among C57BL/6, NK1.1-congenic BALB/c, and NK1.1-congenic nonobese diabetic mice. NKT cells were identified and compared using a range of approaches: NK1.1 expression, surrogate phenotypes used in previous studies, labeling with CD1d/ $\alpha$-galactosylceramide tetramers, and cytokine production. Our results demonstrate that NKT cells and their CD4/ CD8-defined subsets are present in all three strains, and confirm that nonobese diabetic mice have a numerical and functional deficiency in these cells. We also highlight the hazards of using surrogate phenotypes, none of which accurately identify NKT cells, and one in particular $\left(\mathrm{DX5}^{+} \mathrm{CD3}^{+}\right)$actually excludes these cells. Finally, our results support the concept that NK1.1 expression may not be an ideal marker for CD1d-restricted NKT cells, many of which are NK1.1-negative, especially within the CD4 ${ }^{+}$subset and particularly in NK1.1-congenic BALB/c mice. The Journal of Immunology, 2001, 167: 1164-1173.

$\mathrm{T}$ he CD1d-restricted $\mathrm{V} \alpha 14-\mathrm{J} \alpha 281$ invariant $\alpha \beta \mathrm{TCR}^{+}$ $(\mathrm{NKT})^{3}$ cells represent a $\mathrm{T}$ cell lineage that appears to be important in a diversity of immune responses ranging from suppression of autoimmune disease to tumor rejection (reviewed in Ref. 1). These cells have been most extensively studied in the C57BL/6 strain due to its allelic expression of NK1.1, which, in conjunction with the $\alpha \beta \mathrm{TCR}$, is used most frequently in the identification of NKT cells. Most other common laboratory mouse strains (for example BALB/c, CBA, C3H, 129, and nonobese diabetic (NOD)) do not express NK1.1. The reason for this strain-dependent expression of NK1.1 is not known but may be due to a strain-specific transacting factor (2). Until recently, the investigation of NKT cells in non-NK1.1-expressing strains has been hampered by the lack of an alternate marker, although "NKT-like" cells appear to be present. Several surrogate phenotypes have been used to represent NKT cells, for example, CD62 $\mathrm{L}^{-} \mathrm{CD} 24^{-} 3 \mathrm{G}_{11}{ }^{-}(3), \mathrm{CD} 4^{+} \mathrm{CD} 44^{\text {high }}(4), \alpha \beta \mathrm{TCR}^{+} \mathrm{CD} 4{ }^{-}$ $\mathrm{CD}^{-}\left(\alpha \beta^{+} \mathrm{DN}\right)(5), \mathrm{Ly} 49 \mathrm{a}^{+} \mathrm{CD} 122^{+} \mathrm{CD}^{+}(6)$, and $\mathrm{DX} 5^{+} \mathrm{CD}^{+}$ (7). However, it is not clear how accurately these phenotypes identify NKT cells, especially in NK1.1-negative strains.

\footnotetext{
* Department Pathology and Immunology, Monash University, Melbourne, Australia; ${ }^{\dagger}$ Centenary Institute of Cancer Medicine and Cell Biology, Sydney, Australia; ${ }^{*} \mathrm{Di}-$ vision of Developmental Immunology, La Jolla Institute of Allergy and Immunology, San Diego, CA 92121; and ${ }^{\S}$ Department of Microbiology, University of Western Australia, Nedlands, Australia.

Received for publication January 30, 2001. Accepted for publication May 16, 2001 The costs of publication of this article were defrayed in part by the payment of page charges. This article must therefore be hereby marked advertisement in accordance with 18 U.S.C. Section 1734 solely to indicate this fact.

${ }^{1}$ This work was supported by the National Health and Medical Research Council, ADCORP-Diabetes Australia and donations from Rothschild Australia, and by postgraduate scholarships to K.J.L.H. and L.D.P. (Australian Post-Graduate Award).

${ }^{2}$ Address correspondence and reprint requests to Dr. Dale Godfrey, Department of Pathology and Immunology, Monash Medical School, Commercial Road, Prahran, VIC 3181, Australia. E-mail address: Dale.Godfrey@med.monash.edu.au

${ }^{3}$ Abbreviations used in this paper: NKT, CD1d-restricted V $\alpha 14-\mathrm{J} \alpha 281$ invariant $\alpha \beta \mathrm{TCR}^{+} ; \alpha \beta^{+} \mathrm{DN}, \alpha \beta \mathrm{TCR}^{+} \mathrm{CD}^{-} \mathrm{CD}^{-} \mathrm{DN} ; \alpha$-GalCer, $\alpha$-galactosylceramide; BALB.NK1.1, BALB.B6.-Cmv1 ${ }^{r}$; DN, CD4 ${ }^{-} \mathrm{CD}^{-}{ }^{-}$(double negative); NOD.NK1.1, NOD.b-Nkrp $1^{b}$; PLN, peripheral lymph node; NOD, nonobese diabetic.
}

NK1.1 has traditionally been used in the identification of NKT cells, although the use of this marker is complicated by the existence of CD1d-dependent and -independent populations of NK $1.1^{+} \mathrm{T}$ cells $(8,9)$. The CD1d-dependent subset encompasses the cells expressing the invariant $\mathrm{V} \alpha 14-\mathrm{J} \alpha 281$ and biased $\mathrm{V} \beta$ repertoire (8-10), and rapid IL-4-producing potential (10-13). CD1dindependent NK1.1 ${ }^{+} \mathrm{T}$ cells represent a separate lineage, the functional relevance of which is unknown. In this paper, the term "NKT cells" refers to the CD1d-dependent population. Another reagent, tetrameric complexes of CD1d and $\alpha$-galactosylceramide ( $\alpha$-GalCer), has recently been developed to aid in the identification of NKT cells. These complexes have been shown to bind stably and selectively to NKT cells expressing the invariant V $\alpha 14-\mathrm{J} \alpha 281$ TCR $\alpha$-chain in mice or V $\alpha 24-\mathrm{J} \alpha \mathrm{Q}$ TCR in humans, and tetramerlabeled cells were not observed in TCR J $\alpha 281^{-1-}$ and CD $1 d^{-1-}$ mice $(14,15)$. CD1d/ $\alpha$-GalCer tetramers are advantageous in that they detect NKT cells regardless of NK1.1 expression; however, this reagent is limited by the possibility that some CD1d-restricted NKT cells may not react with the $\alpha$-GalCer glycolipid Ag. Here, a combination of both approaches, labeling with anti-NK1.1 as well as CD1d/ $\alpha$-GalCer tetramers, was used in the investigation of NKT cells.

In this study, we have directly compared NKT cells among C57BL/6, BALB/c, and NOD mice. These strains were selected as they are believed to vary widely in their proportions of NKT cells. Using the $\alpha \beta^{+}$DN surrogate phenotype, NOD mice have previously been shown to be deficient in NKT cells, particularly in the thymus $(3,5,16)$. In contrast, BALB/c mice have a high proportion of $\alpha \beta^{+} \mathrm{DN}$ thymocytes and represent a prototypic Th2 responder strain. As NKT cells have been shown to be responsible for the majority of IL-4 produced following thymocyte stimulation (17-19), it was important to determine whether there was a relationship between variations in NKT cells and functional differences between these strains. NK1.1-congenic lines of BALB/c and NOD mice (BALB.B6.-Cmv1 ${ }^{r}$ (BALB.NK1.1) and NOD.b$N_{k r p 1^{b}}$ (NOD.NK1.1), respectively) were used to enable NK1.1 labeling of NKT cells. The development of these congenic mice and $\mathrm{CD} 1 \mathrm{~d} / \alpha$-GalCer tetramers has allowed us to directly compare the number of NKT cells and their CD4/CD8-defined subsets, their 
functional capacity in the form of IL-4/IFN- $\gamma$ production, and to determine the effectiveness of some commonly used surrogate phenotypes on each of these backgrounds.

\section{Materials and Methods Mice}

NK1.1-congenic BALB/c (BALB.NK1.1) (20) and NOD/Lt mice (NOD.NK1.1) (21) were produced by introducing a segment of chromosome 6 containing the NK cell gene complex (22) from C57BL/6J mice onto the BALB/c and NOD/Lt genetic backgrounds, respectively. A minimum of 10 backcrosses were conducted before using these mice. All mice were purchased from the Animal Resources Center (Canning Vale, WA) and housed either under standard conditions in the absence of specific pathogens in the Centenary Institute Animal House (Newtown, New South Wales, Australia) or for 1-2 wk in microisolators in the Monash University Medical School Animal House (Prahran, Victoria, Australia). Mice were used between 6 and $10 \mathrm{wk}$ of age, and were age-matched within each experiment.

\section{Cell suspensions}

Cell suspensions of thymus, spleen, bone marrow, and peripheral lymph nodes (PLNs) were prepared as previously described (10). Hepatic leukocytes were isolated by cutting individual livers into small pieces and gently pressing through 200-gauge wire mesh. The cells were washed twice in ice-cold PBS with $2 \%$ FCS and $0.02 \%$ azide and spun through $33.8 \%$ Percoll (Amersham Pharmacia Biotech, Castle Hill, New South Wales, Australia) for $12 \mathrm{~min}$ at $693 \times \mathrm{g}$. Recovered leukocytes were washed and treated with red cell removal buffer (Sigma, Castle Hill, New South Wales, Australia).

\section{Purification of NKT cells}

To enrich for thymic NKT cells, CD24(HSA) ${ }^{+}$and $\mathrm{CD}^{+}$thymocytes were depleted by incubation with rat anti-mouse CD24 (clone J11D) and rat anti-mouse CD8 (clone 3.155), respectively, followed by rabbit complement (C-six Diagnostics, Germantown, WI). Splenic NKT cells were enriched by incubation with anti-B220 (clone RA3.6B2), anti-CD24 (clone M1/69), and anti-CD62L (clone MEL-14), followed by incubation with anti-rat Ig magnetic beads (Dynal, Carlton, VIC, Australia) and depletion using a magnetic cell separator. Enriched NKT cells were then surfacelabeled for flow cytometric sorting.

\section{Flow cytometry}

The following mAbs were used in multiparameter flow cytometric analysis: anti- $\alpha \beta$ TCR-allophycocyanin (clone H57-597), anti-CD4-FITC or -CD4-PerCP (clone RM4-5), anti-CD8-biotin or -CD8-PerCP (clone 536.7), anti-CD122-biotin (clone TM $\beta-1$ ), anti-NK1.1-PE (clone PK136, mouse IgG2a), anti-DX5-FITC (clone DX5), anti-3G11 disialoganglioside Ag-biotin (clone SM3G11) (all purchased from PharMingen, San Diego, CA), anti-CD4-TRI-COLOR (clone CT-CD4), and anti-CD8-TRI-COLOR (clone CT-CD8 $\alpha$ ) (Caltag Laboratories, Burlingame, CA). Biotinylated mAbs were detected with streptavidin-Alexa Fluor 488 (Molecular Probes, Eugene, OR) or streptavidin-PerCP (PharMingen). Culture supernatants of anti-CD8 (clone 3.155), anti-CD24 (clone M1/69), and anti-CD62L (clone MEL-14) (all grown in-house), and anti-Ly49A (clone YEI-32; a gift of M. Smyth, Peter MacCallum Cancer Institute, Melbourne, Victoria, Australia) were revealed with anti-rat IgG-FITC (Vector Laboratories, Burlingame, $\mathrm{CA}$ ). To prevent any cross-reactive binding of subsequent $\mathrm{mAb}$ to the anti-rat $\mathrm{IgG}$, cells were incubated with normal rat serum after this step. Mouse anti-rat CD44 (clone OX-49, mouse IgG2a) was used as an isotype control for anti-NK1.1. FcR block (anti-CD16/CD32, clone 2.4G2 culture supernatant) was used routinely, except in cases where anti-rat IgG-FITC was being used. PE-labeled, $\alpha$-GalCer-loaded or unloaded (control) mCD1d tetramers were a gift from O. Naidenko and M. Kronenberg (Division of Developmental Immunology, La Jolla Institute of Allergy and Immunology, San Diego, CA), and their generation has been described previously (15). Three- and four-color analysis, as well as multicolor sorting, were performed using a FACSCalibur or FACStar ${ }^{\text {Plus }}$ (BD Biosciences, San Jose, CA). Sorted populations were usually $>95 \%$ pure. CellQuest software (BD Biosciences) was used for analysis.

\section{In vitro $T$ cell stimulation}

Cells were stimulated by culturing in anti-CD3-coated microtiter plates (either KT3-1.1, grown and purified in-house, or 145-2C11, PharMingen). In most cases, cells were cultured at a density of $1 \times 10^{5}$ cells in $100 \mu \mathrm{l}$ tissue culture medium. In some cases $0.5 \times 10^{5}$ cells were cultured per well; in these instances, the same number of NKT cells from each strain was stimulated for direct comparison between the level of cytokines produced. Supernatants were harvested at $18-20 \mathrm{~h}$, and analyzed for cytokine production by ELISA. Cytokine readouts for samples with $0.5 \times 10^{5}$ cells were adjusted to cytokines produced per $10^{5}$ cells.

\section{Cytokine assays}

IL-4 and IFN- $\gamma$ were detected by sandwich ELISA as described previously (10). Generally the limit of detection for IL- 4 was $2 \mathrm{U} / \mathrm{ml}$, and for IFN- $\gamma$ $0.1 \mathrm{ng} / \mathrm{ml}$. Samples with undetectable cytokine levels were assigned the lowest detectable value.

\section{Statistical analysis}

Quantitative differences between two samples were compared with the Mann-Whitney $U$ (rank sum) test. When three groups were being compared, an ANOVA was performed followed by a Tukey post hoc analysis to determine which mouse strain was different. When the data were found not to be normally distributed, or the sample size was small, a KruskalWallis test was used, followed by Dunn's post hoc test.

\section{Results}

\section{NK1.1 $1^{+}$T cells: frequency and tissue distribution}

$\mathrm{NK} 1.1^{+} \mathrm{T}$ cells were clearly present in each strain tested (C57BL/6, NOD.NK1.1, and BALB.NK1.1 mice) and followed a similar tissue-specific distribution in each strain (Fig. 1, Table I). However, there were clear differences between strains in the proportions of $\mathrm{NK}_{1.1}{ }^{+} \mathrm{T}$ cells present in each organ. In the thymus, NOD.NK1.1 mice had considerably fewer NK1.1 ${ }^{+} \mathrm{T}$ cells than C57BL/6 and BALB.NK1.1 in terms of both their proportion and

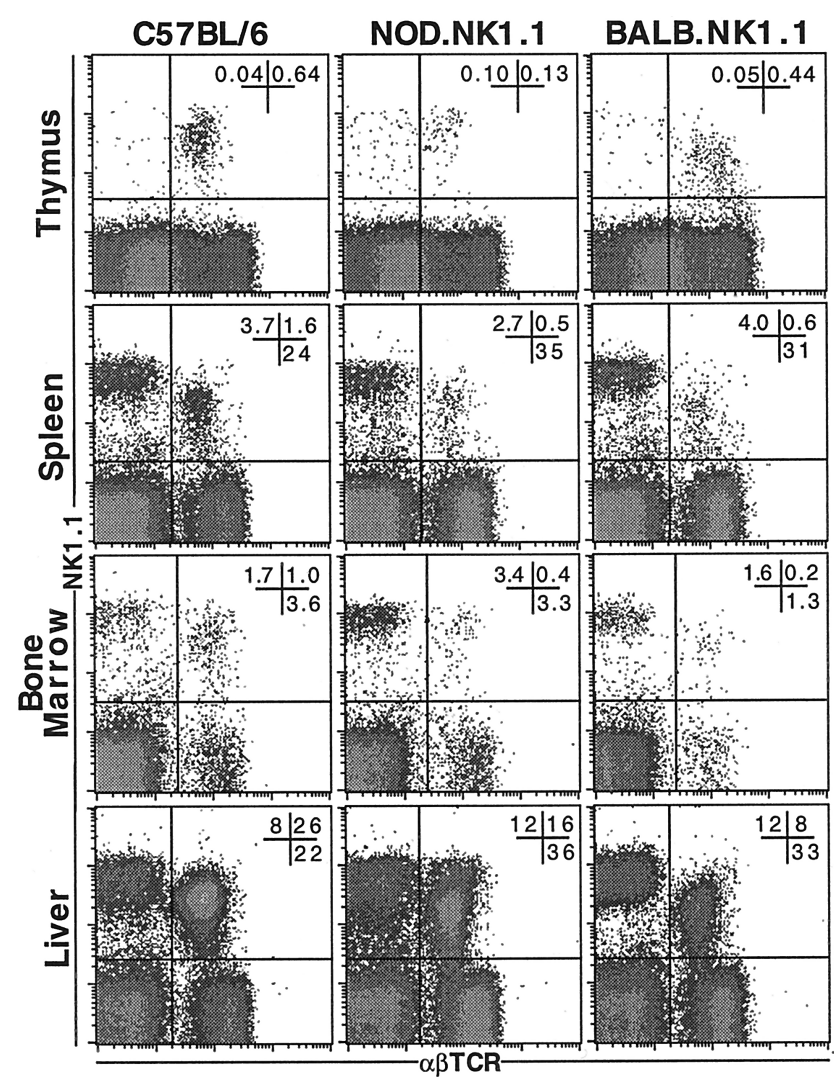

FIGURE 1. NK1.1 ${ }^{+} \mathrm{T}$ cell distribution. Cell suspensions from each tissue were labeled with mAb specific for $\alpha \beta$ TCR and NK1.1. Each density plot shows NK1.1 vs $\alpha \beta$ TCR expression by lymphoid-gated cells. The proportion of lymphoid-gated cells in each quadrant is given in the top right corner of each density plot. Each column represents a sample from the mouse strain indicated. These data are representative of between 5 and 32 tests as detailed in Table I. 
Table I. Tissue distribution of NK1.1 $1^{+}$T cells ${ }^{a}$

\begin{tabular}{|c|c|c|c|c|c|c|c|}
\hline Organ & Strain & $n^{b}$ & $\begin{array}{l}\text { Total Cell No. } \\
\qquad\left(\times 10^{-6}\right)\end{array}$ & $\begin{array}{c}\% \mathrm{NK} 1.1^{+} \alpha \beta \mathrm{TCR}^{+} \\
\left(\mathrm{NK} 1.1^{+} \mathrm{T}\right)\end{array}$ & $\begin{array}{c}\% \mathrm{NK} 1.1^{+} \alpha \beta \mathrm{TCR}^{-} \\
(\mathrm{NK})\end{array}$ & $\begin{array}{c}\%{\mathrm{NK} 1.1^{-} \alpha \beta \mathrm{TCR}^{+}}_{\left(\mathrm{NK} 1.1^{-} \mathrm{T}\right)}\end{array}$ & $\begin{array}{l}\% \text { T Cells That } \\
\text { Express NK1.1 }\end{array}$ \\
\hline \multirow[t]{3}{*}{ Thymus $^{c}$} & C57BL/6 & 31 & $200 \pm 50^{d}$ & $0.45 \pm 0.15$ & $0.05 \pm 0.02$ & & \\
\hline & NOD.NK1.1 & 17 & $145 \pm 40$ & $0.16 \pm 0.07^{* \dagger}$ & $0.10 \pm 0.03 * \dagger$ & & \\
\hline & BALB.NK1.1 & 25 & $230 \pm 90$ & $0.3 \pm 0.1^{* \dagger}$ & $0.04 \pm 0.02^{\dagger}$ & & \\
\hline \multirow[t]{3}{*}{ Spleen } & C57BL/6 & 32 & $110 \pm 20$ & $1.2 \pm 0.5$ & $2.5 \pm 0.7$ & $24 \pm 3$ & $5 \pm 2$ \\
\hline & NOD.NK1.1 & 20 & $90 \pm 25$ & $0.4 \pm 0.1^{*}$ & $2.2 \pm 0.5^{\dagger}$ & $36 \pm 5^{* \dagger}$ & $1.1 \pm 0.2 *$ \\
\hline & BALB.NK1.1 & 25 & $130 \pm 30$ & $0.5 \pm 0.1^{*}$ & $3.9 \pm 0.7 * \dagger$ & $27 \pm 4^{* \dagger}$ & $1.7 \pm 0.4^{*}$ \\
\hline \multirow[t]{3}{*}{ Bone marrow } & C57BL/6 & 24 & $15 \pm 4$ & $0.6 \pm 0.2$ & $1.1 \pm 0.4$ & $2 \pm 1$ & $23 \pm 6$ \\
\hline & NOD.NK1.1 & 10 & $12 \pm 3$ & $0.3 \pm 0.1^{* \dagger}$ & $3.2 \pm 0.6^{* \dagger}$ & $4 \pm 2 *^{\dagger}$ & $8 \pm 4^{*}$ \\
\hline & BALB.NK1.1 & 19 & $12 \pm 3$ & $0.11 \pm 0.05^{\dagger}$ & $1.0 \pm 0.4^{\dagger}$ & $1.0 \pm 0.6^{* \dagger}$ & $11 \pm 4^{*}$ \\
\hline \multirow[t]{3}{*}{ Liver } & C57BL/6 & 20 & $3 \pm 1$ & $20 \pm 6$ & $9 \pm 3$ & $27 \pm 6$ & $40 \pm 10$ \\
\hline & NOD.NK1.1 & 10 & $1.1 \pm 0.5$ & $16 \pm 3 *^{\dagger}$ & $14 \pm 3 *$ & $35 \pm 6^{*}$ & $32 \pm 6^{*}$ \\
\hline & BALB.NK1.1 & 21 & $4 \pm 2$ & $11 \pm 3^{* \dagger}$ & $15 \pm 3^{*}$ & $38 \pm 6^{*}$ & $22 \pm 5^{*}$ \\
\hline \multirow[t]{3}{*}{ PLN } & C57BL/6 & 5 & $26 \pm 3$ & $0.39 \pm 0.05$ & $0.8 \pm 0.1$ & $52 \pm 2$ & $0.74 \pm 0.08$ \\
\hline & NOD.NK1.1 & 5 & $26 \pm 3$ & $0.13 \pm 0.02 *$ & $0.39 \pm 0.09 *$ & $74 \pm 2^{*}$ & $0.18 \pm 0.03^{*}$ \\
\hline & BALB.NK1.1 & 5 & $31 \pm 5$ & $0.13 \pm 0.01 *$ & $0.57 \pm 0.09$ & $70 \pm 1$ & $0.18 \pm 0.02 *$ \\
\hline
\end{tabular}

${ }^{a}$ Cells were labeled with mAb specific for $\alpha \beta$ TCR and NK1.1. Populations were defined based on the quadrants shown in Fig. 1 . $*$, Significantly different from C57BL/6 $(p \leq 0.05) ; \dagger$, significant difference obtained between NOD.NK1.1 and BALB.NK1.1 strains $(p \leq 0.05)$

${ }^{b} n$, No. of samples tested.

${ }^{c}$ The percentage of $\mathrm{NK}_{1.1^{-}} \alpha \beta \mathrm{TCR}^{+}$cells was not determined as most thymocytes are immature $\mathrm{T}$ cells.

${ }^{d}$ Results represent mean $\pm \mathrm{SD}$ for the number of samples indicated, from a minimum of three individual experiments.

number. This was predicted based on our previous results $(5,16$, 23) where NOD mice were shown to have the lowest proportion of $\alpha \beta^{+} \mathrm{DN}$ thymocytes compared with eight other strains tested. However, BALB.NK1.1 mice also had one-third fewer thymic $\mathrm{NK} 1.1^{+} \mathrm{T}$ cells than C57BL/6 mice. This was surprising because $\mathrm{BALB} / \mathrm{c}$ has the highest proportion of $\alpha \beta^{+} \mathrm{DN}$ thymocytes (5). Interestingly, the phenotype of NK1.1 ${ }^{+} \mathrm{T}$ cells in BALB.NK1.1 thymus differed from that of C57BL/6 and NOD.NK1.1 in that most had a lower level of NK1.1 expression and a higher level of $\alpha \beta$ TCR (Fig. 1).

In peripheral organs, the proportion and number of $\mathrm{NK} 1.1^{+} \mathrm{T}$ cells in both BALB.NK1.1 and NOD.NK1.1 mice were generally reduced compared with $\mathrm{C} 57 \mathrm{BL} / 6$. Here, the difference between BALB.NK1.1 and C57BL/6 mice was more pronounced than in the thymus, such that the proportions of $\mathrm{NK} 1.1^{+} \mathrm{T}$ cells in BALB.NK1.1 mice were similar to and, in some cases, lower than in NOD.NK1.1 mice. For example, in the spleen, NOD.NK1.1 and BALB.NK1.1 mice had a mean proportion of 0.4 and $0.5 \%$ NK1.1 $1^{+} \mathrm{T}$ cells respectively, compared with $1.2 \%$ in C57BL/6. NK $1.1^{+}$T cells represented $23 \%$ of $\mathrm{T}$ cells in the bone marrow of $\mathrm{C} 57 \mathrm{BL} / 6$ mice, and were again present in reduced proportions in NOD.NK1.1 and BALB.NK1.1 mice, with BALB.NK1.1 mice having the least. In the liver, NK1.1 ${ }^{+} \mathrm{T}$ cells were found in the highest proportions in C57BL/6 (20\%), then NOD.NK1.1 mice $(16 \%)$, then BALB.NK1.1 mice $(11 \%)$. Very few NK1.1 ${ }^{+}$T cells were detected in the PLNs of C57BL/6 mice, and the proportion was even lower in NOD.NK1.1 and BALB.NK1.1 mice (Table I).

In addition to the variation in NK1.1 ${ }^{+} \mathrm{T}$ cell numbers between strains, some differences were detected in the proportions of NK $1.1^{+} \alpha \beta \mathrm{TCR}^{-}$and $\mathrm{NK}_{1.1^{-}} \alpha \beta \mathrm{TCR}^{+}$cells (Fig. 1, Table I). However, the most consistent difference noted between the strains was the reduction of peripheral NK1.1 ${ }^{+} \mathrm{T}$ cells in NOD.NK1.1 and BALB.NK1.1 mice in comparison to C57BL/6 mice such that the proportion of NK1.1 $1^{+} \mathrm{T}$ cells among total $\mathrm{T}$ cells was always highest in this strain.

\section{Tissue distribution of NK1.1 $1^{+}$T cell subsets}

Given that the proportion of NK1.1 ${ }^{+} \mathrm{T}$ cells varied among the three strains under investigation, and that three distinct subpopu- lations of these cells exist $\left(\mathrm{CD} 4^{+} \mathrm{CD} 8^{-}\left(\mathrm{CD} 4^{+}\right), \mathrm{CD} 4^{-} \mathrm{CD} 8^{-}\right.$ (double negative, $\mathrm{DN})$, and $\mathrm{CD}^{-} \mathrm{CD}^{+}\left(\mathrm{CD} 8^{+}\right)$) $(8-10)$, we sought to determine whether the differences in $\mathrm{NK} 1.1^{+} \mathrm{T}$ cells applied to all of these subsets.

$\mathrm{CD}^{+}$and DN subsets of NK1.1 ${ }^{+} \mathrm{T}$ cells were found in the thymus of all strains (Fig. 2). However, in contrast to C57BL/6 where the $\mathrm{CD}^{+}{ }^{+}$subset is in the majority in the thymus, the DN population was increasingly prominent in NOD.NK1.1 and BALB.NK1.1 mice, respectively. When the total number of each subset was determined, the $\mathrm{CD}^{+}{ }^{+}$subset was found to be lower in BALB.NK1.1 mice, whereas the number of both subsets of thymic NK1.1 ${ }^{+} \mathrm{T}$ cells were reduced in NOD.NK1.1 mice in comparison to $\mathrm{C} 57 \mathrm{BL} / 6$ mice (data not shown).

In the periphery, the proportion of each CD4/CD8-defined subset within the NK1.1 ${ }^{+} \mathrm{T}$ cell population was usually similar between C57BL/6 and BALB.NK1.1 mice. However, the proportion of $\mathrm{NK}_{1.1^{+}} \mathrm{T}$ cells that were $\mathrm{CD}^{+}$was usually lower in NOD.NK1.1 mice than in the other strains (Fig. 2). This reduction did not account for the overall deficiency of peripheral NK1.1 ${ }^{+} \mathrm{T}$ cells in NOD.NK1.1 mice, as the number of DN NK1.1 ${ }^{+} \mathrm{T}$ cells was also decreased when compared with C57BL/6 mice. The $\mathrm{CD} 8^{+}$subset comprised a minor proportion of $\mathrm{NK} 1.1^{+} \mathrm{T}$ cells in the peripheral organs of each mouse strain, although these cells were more abundant in the bone marrow and PLNs of C57BL/6 mice. Taken together, these results indicate that the NK1.1 ${ }^{+} \mathrm{T}$ cell population as a whole varied between strains.

\section{Cytokine production by NK1.1 $1^{+} \mathrm{T}$ cells}

A key feature of NKT cells is their ability to rapidly produce cytokines on primary stimulation. This functional characteristic was investigated and compared in each strain. In the first series of experiments, cytokine production by NK1.1 ${ }^{+} \mathrm{T}$ cells was compared between C57BL/6 and BALB.NK1.1 mice (Table II). $\mathrm{NK} 1.1^{+} \mathrm{T}$ cells isolated from the thymuses of these mice produced high levels of IL-4 after 1 day of anti-CD3 stimulation. The level of IL-4 produced by splenic NK $1.1^{+} \mathrm{T}$ cells was also similar between these two strains and, as previously reported for C57BL/6 mice (10), this level was lower than that produced by thymic NK1.1 ${ }^{+} \mathrm{T}$ cells. IFN- $\gamma$ was also produced by NK1.1 ${ }^{+} \mathrm{T}$ cells 


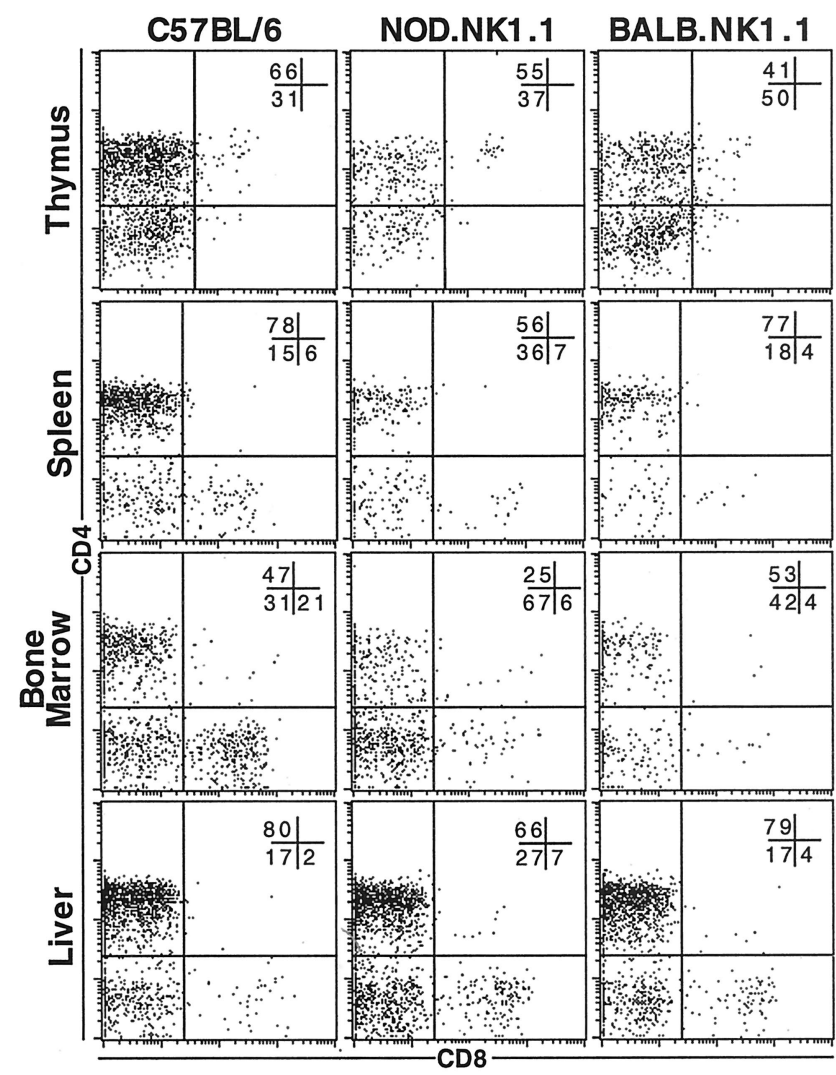

FIGURE 2. Tissue distribution of CD4/CD8-defined NK1.1 ${ }^{+} \mathrm{T}$ cell subsets. Cell suspensions from each tissue were labeled with $\mathrm{mAb}$ specific for $\alpha \beta$ TCR, NK1.1, CD4, and CD8. Each dot plot shows CD4 vs CD8 expression by electronically gated $\mathrm{NK} 1.1^{+} \mathrm{T}$ cells that were enriched by acquisition gating. The proportion of gated cells in each quadrant is given in the top right corner of each dot plot. Each column represents a sample from the mouse strain indicated. These data are representative of between 5 and 32 tests as detailed in Table I.

following stimulation, although the amount varied between strains, and again, less was produced by splenic NK1.1 ${ }^{+} \mathrm{T}$ cells than by thymic NK $1.1^{+} \mathrm{T}$ cells.

In a separate series of experiments, IL- 4 and IFN- $\gamma$ production by $\mathrm{NK} 1.1^{+} \mathrm{T}$ cells was compared between C57BL/6 and NOD.NK1.1 mice. Thymic NKT cells from NOD.NK1.1 mice produced significantly less IL-4 after 1 day of stimulation, compared with NK1.1 ${ }^{+} \mathrm{T}$ cells from C57BL/6 mice (Table III). In contrast, the level of IFN- $\gamma$ produced by thymic NK1.1 ${ }^{+} \mathrm{T}$ cells was similar between these strains. IL-4 production by NOD.NK1.1 $\mathrm{NK} 1.1^{+} \mathrm{T}$ cells from the spleen was also approximately half that of C57BL/6 mice. In this series of experiments, cytokine secretion was also measured after 2 days of stimulation, by which time the level of IL-4 produced by NK1.1 ${ }^{+} \mathrm{T}$ cells from the thymus and spleen of NOD.NK1.1 mice had increased and was comparable to C57BL/6 mice (data not shown). The amount of cytokines produced by NK1.1 ${ }^{+} \mathrm{T}$ cells isolated from C57BL/6 mice varied between these two sets of experiments so that cytokine production by these cells from NOD.NK1.1 and BALB.NK1.1 mice cannot be directly compared. This variation was potentially caused by the use of different anti-CD3 clones for stimulation; in the first series clone KT3 (rat anti-mouse CD3) while in the second series the clone 145-2C11 (hamster anti-mouse-CD3; PharMingen) was used, and we have found the latter reagent to be more effective for cell stimulation (K. J. L. Hammond and D. I. Godfrey, unpublished observation).

Unlike C57BL/6 and NOD.NK1.1 mice, NK1.1-negative T cells from the thymus and spleen of BALB.NK1.1 mice also produced IL-4 and IFN- $\gamma$ following 1 day of anti-CD3 stimulation (Table II). Although these NK1.1-negative cytokine-producing T cells were not fully characterized, in the thymus they resided within a $\mathrm{CD} 4^{+} \mathrm{CD} 8^{-} \mathrm{CD} 24^{-}$phenotype (data not shown).

\section{Strain comparison of CDId/ $\alpha$-GalCer tetramer binding cells}

NK1.1 is the most commonly used marker of NKT cells, particularly in C57BL/6 mice; however, there is evidence indicating that NK1.1-negative T cells exist that appear to have very similar characteristics to NKT cells. These have been described in C57BL/6 mice $(14,15,24)$, but not in other strains. CD1d/ $\alpha$-GalCer tetramers represent an extremely useful reagent because their labeling is dependent on the specific interaction between the restricted TCR and unique ligand (CD1d/ $\alpha$-GalCer) of NKT cells, thereby identifying NKT cells regardless of NK1.1 expression. Thus, we have compared CD1d $/ \alpha$-GalCer tetramer ${ }^{+} \mathrm{T}$ cells to NK1.1 ${ }^{+} \mathrm{T}$ cells in each of the three strains under investigation. CD1d tetramer that had not been loaded with $\alpha$-GalCer was always used as a negative control (Fig. 3A).

The total proportion of CD1d $/ \alpha$-GalCer tetramer-binding T cells is presented in Fig. $3 A$ and Table IV. Surprisingly, in contrast to the results obtained using the NK1.1 marker, the frequency of CD1d-restricted NKT cells was very similar between BALB.NK1.1 and C57BL/6 mice in each organ investigated. Consistent with the data using NK1.1, NOD.NK1.1 mice had fewer thymic CD $1 \mathrm{~d} / \alpha$-GalCer tetramer ${ }^{+} \mathrm{T}$ cells than the other strains, and also had the lowest proportion in the spleen and liver. The proportion of CD1d/ $\alpha$-GalCer tetramer ${ }^{+} \mathrm{T}$ cells in the bone marrow of NOD.NK1.1 mice was lower than in C57BL/6 mice but not different from BALB.NK1.1. The thymus and spleen of BALB.NK1.1 mice contained 3- to 4-fold more CD1d/ $\alpha$-GalCer tetramer $^{+}$T cells than NKT cells (Table IV). In concordance with the data using NK1.1 (Fig. 1), the expression of $\alpha \beta$ TCR by CD1d/

Table II. Cytokine production by NK1.1 ${ }^{+}$T cells from C57BL/6 and BALB.NK1.1 mice ${ }^{a}$

\begin{tabular}{|c|c|c|c|c|c|c|c|c|c|}
\hline \multirow[b]{2}{*}{ Organ } & \multirow[b]{2}{*}{ Strain } & \multicolumn{4}{|c|}{ IL-4 (U/ml) } & \multicolumn{4}{|c|}{ IFN- $\gamma(\mathrm{ng} / \mathrm{ml})$} \\
\hline & & $n^{b}$ & $\mathrm{NK} 1.1^{+} \mathrm{T}$ & $n$ & $\mathrm{NK} 1.1^{-} \mathrm{T}$ & $n$ & $\mathrm{NK} 1.1^{+} \mathrm{T}$ & $n$ & $\mathrm{NK} 1.1^{-} \mathrm{T}$ \\
\hline Thymus & $\begin{array}{l}\text { C57BL/6 } \\
\text { BALB.NK1.1 }\end{array}$ & $\begin{array}{l}22 \\
21\end{array}$ & $\begin{array}{l}600 \pm 100^{c} \\
700 \pm 200\end{array}$ & $\begin{array}{l}22 \\
22\end{array}$ & $\begin{array}{c}16 \pm 4 \\
900 \pm 250^{*}\end{array}$ & $\begin{array}{l}15 \\
14\end{array}$ & $\begin{array}{l}4.8 \pm 0.5 \\
1.3 \pm 0.2^{*}\end{array}$ & $\begin{array}{l}15 \\
15\end{array}$ & $\begin{array}{l}0.1 \pm 0.0 \\
0.9 \pm 0.2 *\end{array}$ \\
\hline Spleen & $\begin{array}{l}\text { C57BL/6 } \\
\text { BALB.NK1.1 }\end{array}$ & $\begin{array}{l}12 \\
12\end{array}$ & $\begin{array}{l}130 \pm 50 \\
200 \pm 90\end{array}$ & $\begin{array}{l}17 \\
18\end{array}$ & $\begin{array}{l}13 \pm 3 \\
36 \pm 9^{\dagger}\end{array}$ & $\begin{array}{l}8 \\
8\end{array}$ & $\begin{array}{l}0.2 \pm 0.0 \\
0.8 \pm 0.2^{\dagger}\end{array}$ & $\begin{array}{l}13 \\
13\end{array}$ & $\begin{array}{l}0.1 \pm 0.0 \\
0.1 \pm 0.0\end{array}$ \\
\hline
\end{tabular}

${ }^{a}$ Supernatant was harvested from FACS-sorted NK1.1 ${ }^{+} \alpha \beta \mathrm{TCR}^{+}$cells and NK1.1 ${ }^{-} \alpha \beta \mathrm{TCR}^{+}$cells after stimulation for $18-20 \mathrm{~h}$ on anti-CD3-coated microtiter plates. IL-4 and IFN- $\gamma$ were then measured in supernatants by ELISA. Cells were cultured at a density of $1 \times 10^{6} \mathrm{cells} / \mathrm{ml}$.

${ }^{b} n$, No. of replicate culture samples tested.

${ }^{c}$ Results represent mean $\pm \mathrm{SE}$ for the number of samples indicated, from two to eight individual experiments. T, $\alpha \beta \mathrm{TCR}{ }^{+}$cells; * $p \leq 0.0005 ; \dagger, p \leq 0.05$ (Mann-Whitney $U$ rank sum test). 
Table III. Cytokine production by NK1.1 ${ }^{+}$T cells from C57BL/6 and NOD.NK1.1 mice ${ }^{a}$

\begin{tabular}{|c|c|c|c|c|c|c|c|c|c|}
\hline \multirow[b]{2}{*}{ Organ } & \multirow[b]{2}{*}{ Strain } & \multicolumn{4}{|c|}{ IL-4 (U/ml) } & \multicolumn{4}{|c|}{ IFN- $\gamma(\mathrm{ng} / \mathrm{ml})$} \\
\hline & & $n^{b}$ & $\mathrm{NK} 1.1^{+} \mathrm{T}$ & $n$ & NK1.1 $1^{-} \mathrm{T}$ & $n$ & $\mathrm{NK} 1.1^{+} \mathrm{T}$ & $n$ & $\mathrm{NK} 1.1^{-} \mathrm{T}$ \\
\hline \multirow[t]{2}{*}{ Thymus } & C57BL/6 & 9 & $1200 \pm 100^{c}$ & 6 & $15 \pm 4$ & 9 & $7 \pm 1$ & 6 & $0.1 \pm 0.0$ \\
\hline & NOD.NK1.1 & 7 & $380 \pm 90 *$ & 6 & $5 \pm 1$ & 6 & $10 \pm 2$ & 6 & $0.1 \pm 0.0$ \\
\hline \multirow[t]{2}{*}{ Spleen } & C57BL/6 & 6 & $560 \pm 80$ & 6 & $7 \pm 1$ & 6 & $0.3 \pm 0.1$ & 6 & $1.2 \pm 0.3$ \\
\hline & NOD.NK1.1 & 6 & $240 \pm 20 *$ & 6 & $7 \pm 1$ & 6 & $1.0 \pm 0.3^{\dagger}$ & 6 & $0.7 \pm 0.1$ \\
\hline
\end{tabular}

${ }^{a}$ Supernatant was harvested from FACS-sorted NK1.1 ${ }^{+} \alpha \beta \mathrm{TCR}^{+}$cells and NK1.1 ${ }^{-} \alpha \beta \mathrm{TCR}^{+}$cells after stimulation for $18-20 \mathrm{~h}$ on anti-CD3-coated microtiter plates. IL-4 and IFN- $\gamma$ were then measured in supernatants by ELISA. Cells were cultured at a density of $1 \times 10^{6}$ cells $/ \mathrm{ml}$

${ }^{b} n$, No. of replicate culture samples tested.

${ }^{c}$ Results represent mean $\pm \mathrm{SE}$ for the number of samples indicated, from two to eight individual experiments. T, $\alpha \beta \mathrm{TCR}{ }^{+}$cells; $*, p \leq 0.005 ; \dagger, p \leq 0.05$ (Mann-Whitney $\mathrm{U}$ rank sum test)

$\alpha$-GalCer tetramer ${ }^{+} \mathrm{T}$ cells in the thymus, and to a lesser extent, the spleen of BALB.NK1.1 mice, ranged from intermediate to high levels, similar to the level of expression by conventional $\mathrm{T}$ cells (Fig. 3A). Non-NK1.1-congenic NOD/Lt and BALB/c mice were also investigated, and no differences were detected in the proportions of CD $1 \mathrm{~d} / \alpha$-GalCer tetramer ${ }^{+} \mathrm{T}$ cells between these strains and the corresponding NK1.1-congenic strain in any organ tested (Table V). The level of $\alpha \beta$ TCR expression by CD1d/ $\alpha$-GalCer tetramer $^{+}$thymocytes in BALB/c mice was also very similar to that of BALB.NK1.1 mice (data not shown).

Upon examination of $\alpha \beta \mathrm{TCR}^{+}$cells colabeled for NK1.1 and $\mathrm{CD} 1 \mathrm{~d} / \alpha$-GalCer tetramer, the reason for the discrepancy between the proportions of cells labeled with these two markers became clear. In C57BL/6 mice, most CD1d $/ \alpha$-GalCer tetramer-binding T cells also expressed NK1.1 (Fig. 4). In line with previous reports
(14, 15), NK1.1-negative CD1d/ $\alpha$-GalCer tetramer-binding T cells were also identified in this strain, and comprised a minority of CD1d $/ \alpha$-GalCer tetramer ${ }^{+} \mathrm{T}$ cells in most organs (Fig. 4, Table VI). In NOD.NK1.1 mice, the fraction of NK1.1-negative cells among CD1d $/ \alpha$-GalCer tetramer ${ }^{+} \mathrm{T}$ cells was larger; the proportion ranged from $17 \%$ in the liver to $45 \%$ in the thymus and bone marrow, and $65 \%$ in the spleen. In BALB.NK1.1 mice, the majority $(70-75 \%)$ of $\mathrm{CD} 1 \mathrm{~d} / \alpha$-GalCer tetramer ${ }^{+}$NKT cells were NK1.1-negative in the thymus and spleen of this strain; this population comprised nearly half of the CD1d/ $\alpha$-GalCer tetramer ${ }^{+}$ NKT cells in the bone marrow and liver. Furthermore, these cells were predominantly $\mathrm{CD}^{+}$(Fig. $3 B$ ). When considering CD $1 \mathrm{~d} / \alpha-$ GalCer tetramer ${ }^{+} \mathrm{T}$ cells, the ratio of $\mathrm{CD} 4^{+}$and $\mathrm{CD} 4^{-}$cells was similar in the thymus of each strain; however, there were some small variations in the proportions of these subsets in other tissues.
A. Total lymphocytes

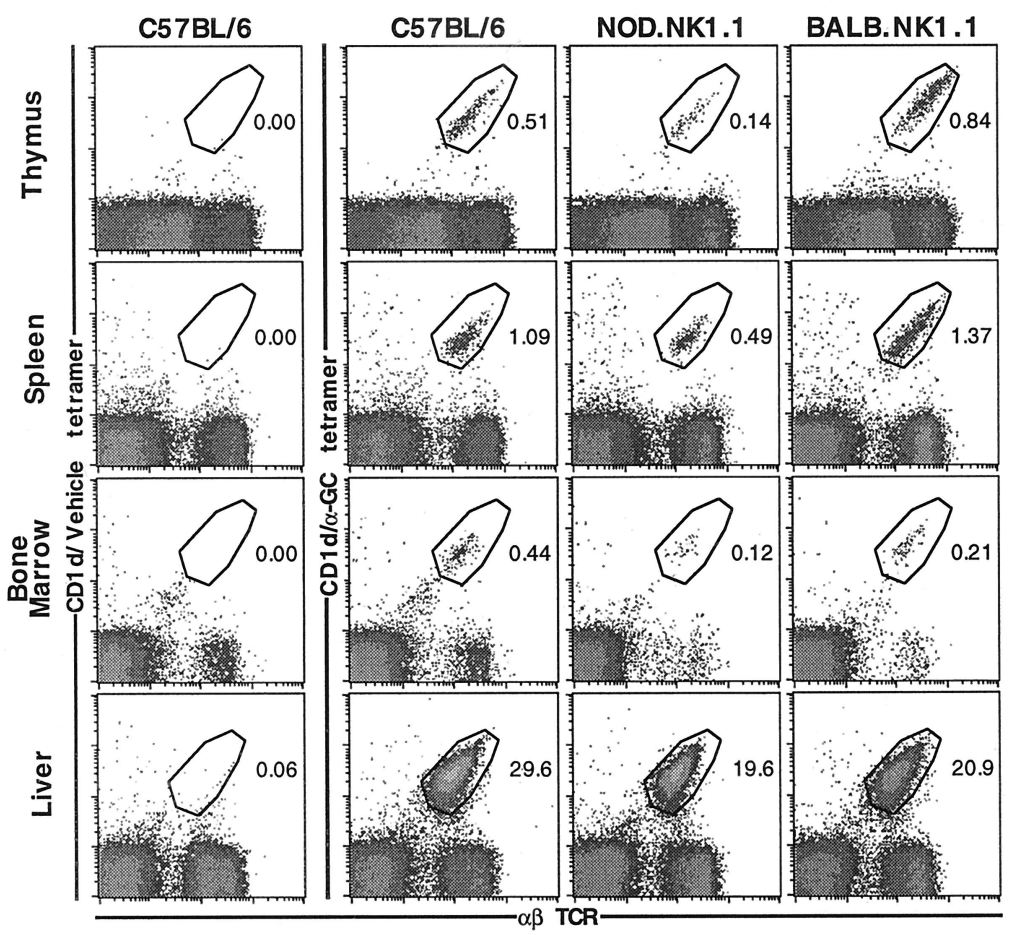

B. CD1d/ $\alpha-\mathrm{GC}^{+} \alpha \beta \mathrm{TCR}^{+}$lymphocytes

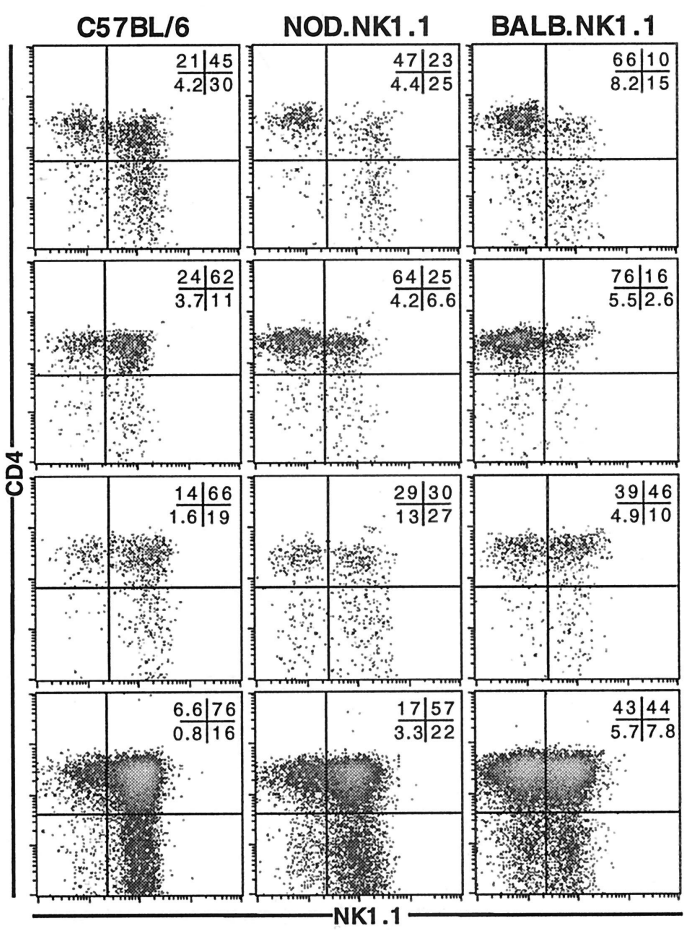

FIGURE 3. CD1d $/ \alpha$-GalCer tetramer vs $\alpha \beta$ TCR expression $(A)$ and CD 4 vs NK1.1 expression on CD1d $/ \alpha$-GalCer tetramer ${ }^{+} \alpha \beta \mathrm{TCR}^{+}$cells $(B)$. Cell suspensions from each tissue were labeled with CD1d/ $\alpha$-GalCer tetramer and mAb specific for $\alpha \beta T C R$, NK1.1, and CD4. A, Each density plot shows $\mathrm{CD} 1 \mathrm{~d} / \alpha$-GalCer tetramer vs $\alpha \beta$ TCR expression by lymphoid-gated cells. The first column shows control tetramer labeling (CD1d/vehicle tetramer) vs $\alpha \beta$ TCR on C57BL/6. Similar controls were conducted on the other two strains (data not shown). The number represents the proportion of lymphoid-gated cells within the region indicated. $B$, Density plots show CD4 vs NK1.1 expression by $\alpha \beta \mathrm{TCR}^{+} \mathrm{CD} 1 \mathrm{~d} / \alpha-\mathrm{GalCer}$ tetramer ${ }^{+}$cells, gated as shown in $A$. The proportion of gated cells in each quadrant is given in the top right corner of each density plot. Each column represents a sample from the mouse strain indicated. These data are representative of nine separate mice. 
Table IV. Comparison of NK1.1 $1^{+}$and CD1d/ $\alpha$-GalCer ${ }^{+}$T cell proportions ${ }^{a}$

\begin{tabular}{|c|c|c|c|c|c|}
\hline Organ & Strain & $\begin{array}{l}\text { Total Cell No. } \\
\quad\left(\times 10^{-6}\right)\end{array}$ & $\begin{array}{c}\% \text { Total CD1d } / \alpha-\mathrm{GC}^{+} \\
\alpha \beta \mathrm{TCR}^{+} \text {Cells }\end{array}$ & $\begin{array}{l}\% \text { Total NK1.1 }{ }^{+} \\
\alpha \beta \mathrm{TCR}^{+} \text {Cells }\end{array}$ & $\begin{array}{c}\text { Ratio CD1d } / \alpha-\mathrm{GC}^{+}: \\
\mathrm{NK} 1.1^{+} \alpha \beta \mathrm{TCR}^{+} \text {Cells }\end{array}$ \\
\hline Thymus & $\begin{array}{l}\text { C57BL/6 } \\
\text { NOD.NK1.1 } \\
\text { BALB.NK1.1 }\end{array}$ & $\begin{array}{l}190 \pm 30^{b} \\
170 \pm 40 \\
170 \pm 50\end{array}$ & $\begin{aligned} 0.6 & \pm 0.2 \\
0.16 & \pm 0.05^{* \dagger} \\
0.8 & \pm 0.3^{\dagger}\end{aligned}$ & $\begin{aligned} 0.6 & \pm 0.24 \\
0.16 & \pm 0.04^{* \dagger} \\
0.3 & \pm 0.2^{\dagger}\end{aligned}$ & $\begin{aligned} 1.1 & \pm 0.1 \\
1.1 & \pm 0.2^{\dagger} \\
3 & \pm 1^{* \dagger}\end{aligned}$ \\
\hline Spleen & $\begin{array}{l}\text { C57BL/6 } \\
\text { NOD.NK1.1 } \\
\text { BALB.NK1.1 }\end{array}$ & $\begin{array}{l}100 \pm 10 \\
100 \pm 30 \\
130 \pm 30\end{array}$ & $\begin{array}{l}1.1 \pm 0.2 \\
0.6 \pm 0.2^{* \dagger} \\
1.4 \pm 0.1^{\dagger}\end{array}$ & $\begin{array}{c}0.9 \pm 0.2 \\
0.36 \pm 0.05^{*} \\
0.35 \pm 0.08^{*}\end{array}$ & $\begin{array}{l}1.2 \pm 0.1 \\
1.7 \pm 0.5^{\dagger} \\
4 \pm 0.8^{* \dagger}\end{array}$ \\
\hline Bone marrow & $\begin{array}{l}\text { C57BL/6 } \\
\text { NOD.NK1.1 } \\
\text { BALB.NK1.1 }\end{array}$ & $\begin{array}{l}11 \pm 2 \\
10 \pm 2 \\
10 \pm 1\end{array}$ & $\begin{array}{c}0.40 \pm 0.08 \\
0.13 \pm 0.05^{*} \\
0.2 \pm 0.1\end{array}$ & $\begin{array}{c}0.7 \pm 0.1 \\
0.26 \pm 0.05 \\
0.17 \pm 0.08^{*}\end{array}$ & $\begin{array}{l}0.6 \pm 0.0 \\
0.5 \pm 0.1^{\dagger} \\
1.3 \pm 0.1^{\dagger}\end{array}$ \\
\hline Liver & $\begin{array}{l}\text { C57BL/6 } \\
\text { NOD.NK1.1 } \\
\text { BALB.NK1.1 }\end{array}$ & $\begin{array}{c}1.9 \pm 0.5 \\
1.8 \pm 0.8 \\
2 \pm 1\end{array}$ & $\begin{array}{l}27 \pm 5 \\
18 \pm 4^{* \dagger} \\
26 \pm 4^{\dagger}\end{array}$ & $\begin{array}{l}26 \pm 5 \\
21 \pm 4 \\
17 \pm 4 *\end{array}$ & $\begin{array}{l}1.0 \pm 0.2 \\
0.9 \pm 0.1^{\dagger} \\
1.6 \pm 0.3^{\dagger}\end{array}$ \\
\hline
\end{tabular}

${ }^{a}$ Cells were labeled with mAb specific for $\alpha \beta$ TCR, NK1.1, and CD1d $/ \alpha$-GalCer tetramer. Regions were set as shown in Fig. $3 A$.

${ }^{b}$ Results represent mean \pm SD for nine mice of each strain, from five individual experiments, except for the bone marrow data, which are derived from five mice from three experiments. CD1d $/ \alpha$-GC, CD1d $/ \alpha$-GalCer tetramer; *, Significantly different from C57BL/6 ( $p \leq 0.05)$; $\dagger$, significant difference obtained between NOD.NK1.1 and BALB.NK1.1 strains $(p \leq 0.05)$.

For example, BALB.NK1.1 mice had the highest proportion of $\mathrm{CD}^{+}{ }^{+} \mathrm{CD} 1 \mathrm{~d} / \alpha-$ GalCer tetramer ${ }^{+} \mathrm{T}$ cells in the spleen (Fig. $3 B$ ).

A population of $\mathrm{NK} 1.1^{+} \mathrm{T}$ cells was also identified in all strains that did not bind the CD1d/ $\alpha$-GalCer tetramer (Fig. 4, Table VI). These cells represented a greater proportion of NKT cells in the spleen and the bone marrow of all strains, and were higher in NOD.NK1.1 mice.

\section{Assessment of surrogate phenotypes for CDId-restricted NKT cells}

Due to the absence of NK1.1 expression in most mouse strains, many studies have relied on other markers, or combinations thereof, in an attempt to identify NKT cells in mice other than C57BL/6. However, it is not clear how well these surrogate phenotypes distinguish NKT cells, particularly in NK1.1-negative strains such as BALB/c and NOD where they have most commonly been used. Here, we have compared the cells identified with surrogate markers to $\mathrm{NK} 1.1^{+}$and $\mathrm{CD} 1 \mathrm{~d} / \alpha-\mathrm{GalCer}$ tetramer ${ }^{+} \mathrm{T}$ cells in the three strains under investigation.

$\mathrm{CDS}^{-} \mathrm{CD}^{-} 4^{-} \mathrm{CD} 2 \mathrm{~L}^{-} 3 \mathrm{G11}{ }^{-} \mathrm{T}$ cells. NOD mice were reported to have a numerical and functional deficiency in NKT cells based on the lower proportion of $\alpha \beta \mathrm{TCR}^{+} \mathrm{CD}_{2} \mathrm{~L}^{-} 3 \mathrm{G} 11^{-}$cells found among $\mathrm{CD}^{-} \mathrm{CD}^{-} \mathrm{CD} 24^{-}$thymocytes in this strain (3). Also, IL-4 production by $\mathrm{CD} 8^{-} \mathrm{CD} 24^{-}$thymocytes from NOD mice following stimulation was lower than the corresponding cells isolated from $\mathrm{C} 57 \mathrm{BL} / 6, \mathrm{BALB} / \mathrm{c}, \mathrm{C} 3 \mathrm{H} / \mathrm{He}$, and $\mathrm{DBA} / 2$ mice. We found that this phenotype was one of the most reliable for distinguishing

Table V. Proportion of CDId/ $\alpha$-GalCer ${ }^{+} T$ cells in NK1.1-congenic and noncongenic BALB/c and NOD/Lt strains ${ }^{a}$

\begin{tabular}{lcccc}
\hline \hline \multirow{2}{*}{\multicolumn{1}{c}{ Strain }} & & \multicolumn{3}{c}{ Organ } \\
\cline { 3 - 5 } & $n^{b}$ & Thymus & Spleen & Liver \\
\hline C57BL/6 & 9 & $0.6 \pm 0.2^{c}$ & $1.1 \pm 0.2$ & $27 \pm 5$ \\
NOD.NK1.1 & 9 & $0.16 \pm 0.05$ & $0.6 \pm 0.2$ & $18 \pm 4$ \\
NOD/Lt & 4 & $0.15 \pm 0.1$ & $0.58 \pm 0.03$ & $18 \pm 3$ \\
BALB.NK1.1 & 9 & $0.8 \pm 0.3$ & $1.4 \pm 0.1$ & $26 \pm 4$ \\
BALB/c & 4 & $0.74 \pm 0.04$ & $1.3 \pm 0.2$ & $22 \pm 5$ \\
\hline
\end{tabular}

${ }^{a}$ Cells were labeled with mAb specific for $\alpha \beta$ TCR and CD1d $/ \alpha$-GalCer tetramer. Regions were set as shown in Fig. $3 A$.

${ }^{b} n$, No. of samples tested.

${ }^{c}$ Results represent mean $\pm \mathrm{SD}$ for the number of samples indicated, from a minimum of two individual experiments. CD1d/ $\alpha$-GC, CD1d/ $\alpha$-GalCer tetramer.
NKT cells, particularly in the liver, and to a lesser extent in the thymus (Fig. 5A, Table VII). However, in the spleen, few T cells with this phenotype expressed NK1.1, and the proportion that was $\mathrm{CD} 1 \mathrm{~d} / \alpha-$ GalCer tetramer ${ }^{+}$was lower and varied between strains. Furthermore, as NKT cells appear to express low to intermediate levels of these surface markers (dashed line in Fig. $5 A$ ), a significant fraction of them may be excluded by this phenotype.

CD3/ $\alpha \boldsymbol{\beta}$ CR $^{+}$CD122 $^{+} \mathrm{Ly} \mathrm{H9A}^{+} \mathrm{T}$ cells. This surface marker phenotype has been used to identify and purify NKT cells from

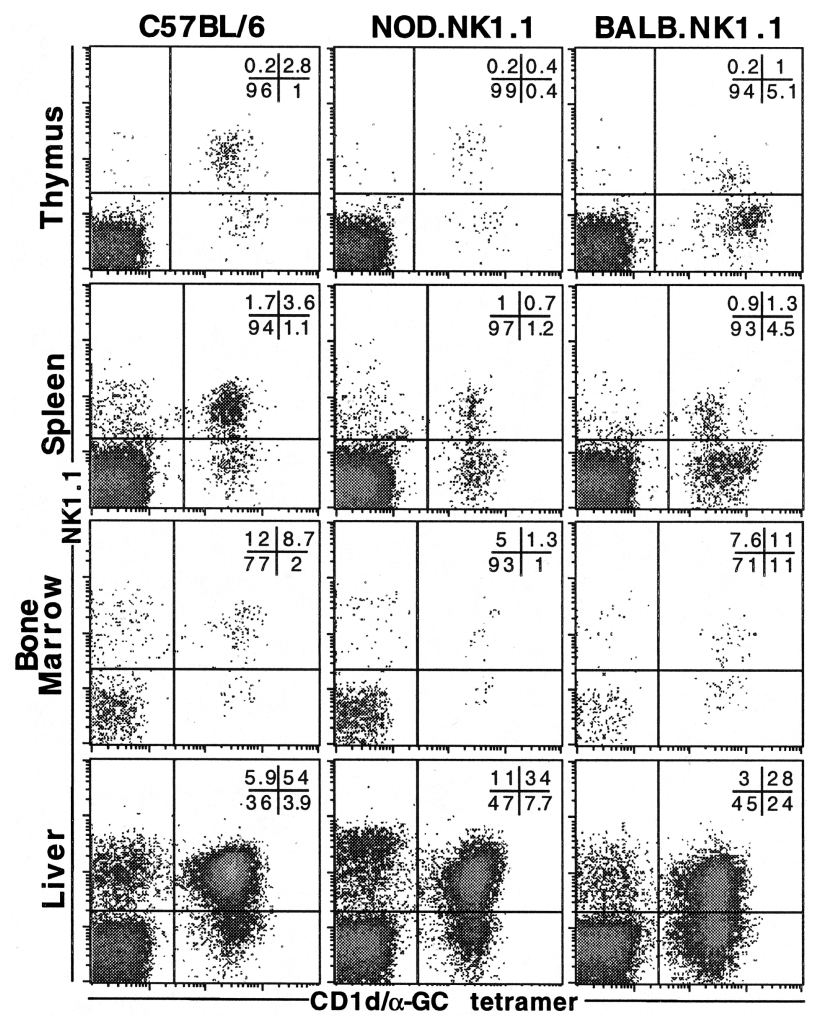

FIGURE 4. Comparison of CD1d/ $\alpha$-GalCer tetramer vs NK1.1 expression on T cells. Cell suspensions from each tissue were labeled with CD1d/ $\alpha$-GalCer tetramer and mAb specific for $\alpha \beta$ TCR and NK1.1. Each density plot shows CD1d/ $\alpha$-GalCer tetramer vs NK1.1 expression by lymphoidgated $\alpha \beta \mathrm{TCR}^{+}$cells. Each column represents a sample from the mouse strain indicated. These data are representative of nine separate mice. 
Table VI. NK1.1 vs CD1d/ $\alpha$-GalCer tetramer labeling of T cells between strains ${ }^{a}$

\begin{tabular}{|c|c|c|c|c|c|}
\hline Organ & Strain & $\begin{array}{c}\% \alpha \beta \mathrm{TCR}^{+} \text {Cells That } \\
\text { Express NK1.1 }\end{array}$ & $\begin{array}{c}\% \alpha \beta \mathrm{TCR}^{+} \text {Cells That } \\
\text { Bind CD } 1 \mathrm{~d} / \alpha-\mathrm{GC}\end{array}$ & $\begin{array}{l}\% \text { NK1.1 }{ }^{+} \text {T Cells That } \\
\text { Do Not Bind CD1d } / \alpha-G C\end{array}$ & $\begin{array}{l}\% \mathrm{CD} 1 \mathrm{~d} / \alpha-\mathrm{GC}^{+} \mathrm{T} \text { Cells That } \\
\text { Do Not Express NK1.1 }\end{array}$ \\
\hline Thymus $^{b}$ & $\begin{array}{l}\text { C57BL/6 } \\
\text { NOD.NK1.1 } \\
\text { BALB.NK1.1 }\end{array}$ & $\begin{array}{l}3.6 \pm 0.8^{c} \\
0.8 \pm 0.2^{* \dagger} \\
2 \pm 1\end{array}$ & $\begin{array}{c}4.1 \pm 0.8 \\
1.0 \pm 0.2^{* \dagger} \\
5 \pm 2^{\dagger}\end{array}$ & $\begin{array}{l}11 \pm 4 \\
30 \pm 10 * \\
18 \pm 3\end{array}$ & $\begin{array}{l}21 \pm 5 \\
45 \pm 8^{*} \\
70 \pm 10^{*}\end{array}$ \\
\hline Spleen & $\begin{array}{l}\text { C57BL/6 } \\
\text { NOD.NK1.1 } \\
\text { BALB.NK1.1 }\end{array}$ & $\begin{array}{l}5.6 \pm 0.9 \\
2.4 \pm 0.9^{*} \\
2.6 \pm 0.7^{*}\end{array}$ & $\begin{aligned} 5 & \pm 1 \\
2.4 & \pm 0.9^{* \dagger} \\
6 & \pm 1^{\dagger}\end{aligned}$ & $\begin{array}{l}34 \pm 3 \\
70 \pm 10^{* \dagger} \\
41 \pm 6^{\dagger}\end{array}$ & $\begin{array}{l}24 \pm 5 \\
65 \pm 6^{*} \\
75 \pm 5^{*}\end{array}$ \\
\hline Bone marrow & $\begin{array}{l}\text { C57BL/6 } \\
\text { NOD.NK1.1 } \\
\text { BALB.NK1.1 }\end{array}$ & $\begin{array}{c}24 \pm 9 \\
9 \pm 2 * \\
18 \pm 6\end{array}$ & $\begin{aligned} 13 & \pm 4 \\
4 & \pm 1^{\dagger} \\
21 & \pm 10^{\dagger}\end{aligned}$ & $\begin{array}{l}57 \pm 2 \\
78 \pm 4^{\dagger} \\
50 \pm 10^{\dagger}\end{array}$ & $\begin{array}{l}18 \pm 4 \\
46 \pm 2 \\
51 \pm 4^{*}\end{array}$ \\
\hline Liver & $\begin{array}{l}\text { C57BL/6 } \\
\text { NOD.NK1.1 } \\
\text { BALB.NK1.1 }\end{array}$ & $\begin{array}{l}55 \pm 7 \\
42 \pm 9 \\
32 \pm 9 *\end{array}$ & $\begin{array}{l}52 \pm 6 \\
36 \pm 8^{* \dagger} \\
49 \pm 7^{\dagger}\end{array}$ & $\begin{array}{l}12 \pm 1 \\
28 \pm 8^{* \dagger} \\
10 \pm 2^{\dagger}\end{array}$ & $\begin{array}{c}6 \pm 2 \\
17 \pm 7 * \\
40 \pm 10^{*}\end{array}$ \\
\hline
\end{tabular}

${ }^{a}$ Cells were labeled with $\mathrm{mAb}$ specific for $\alpha \beta \mathrm{TCR}$, NK1.1, and CD1d/ $\alpha$-GalCer tetramer. $\alpha \beta \mathrm{TCR}^{+}$cells were electronically gated and analyzed for their expression of NK1.1 and $\mathrm{CD} 1 \mathrm{~d} / \alpha$-GalCer tetramer, as shown in Fig. $3 B$.

${ }^{b} \alpha \beta T C R^{\text {high }}$ cells were analyzed in the thymus.

${ }^{c}$ Results represent mean \pm SD for nine mice of each strain, from five individual experiments, except for the bone marrow data, which are derived from five mice from three experiments. CD $1 \mathrm{~d} / \alpha-\mathrm{GC}, \mathrm{CD} 1 \mathrm{~d} / \alpha$-GalCer tetramer; *, Significantly different from C57BL/6 ( $p \leq 0.05)$; $\dagger$, significant difference obtained between NOD.NK1.1 and BALB.NK1.1 strains $(p \leq 0.05)$.

NOD mice for adoptive transfer studies (6). However, when isolated from the spleen of C57BL/6 mice, $\mathrm{CD}^{+}{ }^{+} \mathrm{CD} 122^{+} \mathrm{Ly}_{49 \mathrm{~A}^{+} \mathrm{T}}$ cells produced IFN- $\gamma$ but not IL- 4 after anti- $\alpha \beta$ TCR stimulation in vitro (6). Examination of this phenotype in NK1.1-congenic strains, or using CD1d $/ \alpha$-GalCer tetramers, indicates that although it may highly enrich for a subset of NKT cells, these represent only a small minority: $5-16 \%$ of the total NKT cell population (Fig. $5 B$, Table VII). As the expression of Ly49A was found to be much lower in BALB.NK1.1 mice (data not shown), this phenotype was not appropriate for use in this strain.

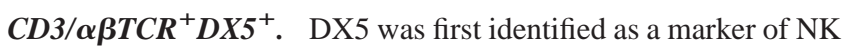
cells (25). Although several recent studies have used this marker to identify NKT cells $(7,26)$, we and others have shown that most NK1.1 ${ }^{+} \mathrm{T}$ cells in C57BL/6 mice do not express DX5 $(8,10)$. Here, we demonstrate that DX5 is not expressed by CD1d/ $\alpha$ GalCer tetramer-binding NKT cells in any of the strains under investigation (Fig. 5C, Table VII).

$\boldsymbol{\alpha} \boldsymbol{\beta}^{+} \boldsymbol{D N}$ cells. The $\alpha \beta^{+}$DN phenotype has been used, particularly in the thymus, to represent NKT cells in strains where NK1.1 was not expressed $(5,27,28)$. It is known that NKT cells represent $\sim 30 \%$ of these cells in C57BL/6 mouse thymus (29). As we have reported, the proportion of thymic DN cells that express the $\alpha \beta$ TCR varies among mouse strains, with $\mathrm{BALB} / \mathrm{c}$ having the highest, and NOD mice the lowest, among the strains tested (5). Despite the variation in $\alpha \beta^{+} \mathrm{DN}$ thymocytes, the fraction that expressed NK1.1 was highly conserved between all three strains ( $\sim 30 \%$ ); however, more $\alpha \beta^{+} \mathrm{DN}$ thymocytes in BALB.NK1.1 mice bound $\mathrm{CD} 1 \mathrm{~d} / \alpha$-GalCer tetramer (Table VII). In the periphery, the proportion of $\alpha \beta^{+} \mathrm{DN}$ cells also differed between strains (data not shown), as did the percentage that expressed NK1.1 or bound $\mathrm{CD} 1 \mathrm{~d} / \alpha-\mathrm{GalCer}$ tetramer. In the liver, most $\alpha \beta^{+} \mathrm{DN}$ cells were NKT cells; however, few splenic $\alpha \beta^{+}$DN cells were CD1d/ $\alpha$-GalCer tetramer ${ }^{+}$. These results indicate that although the $\alpha \beta^{+}$DN phenotype enriches for NKT cells in the thymus and liver, it may be an overestimate of DN NKT cells, and obviously does not account for $\mathrm{CD}^{+}{ }^{+} \mathrm{NKT}$ cells. Furthermore, this phenotype cannot be used to accurately represent these cells in the periphery, as the proportion that were NK $1.1^{+}$or CD1d/ $\alpha$-GalCer tetramer ${ }^{+}$ was not conserved between organs or mouse strains.

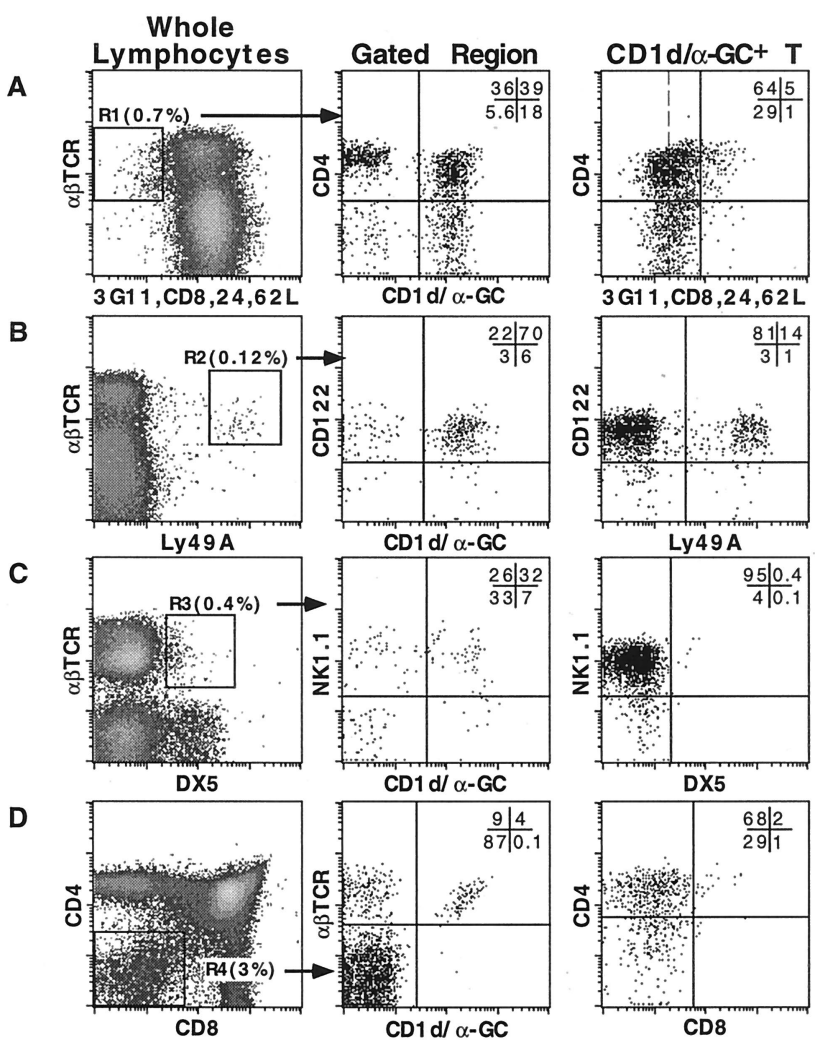

FIGURE 5. Analysis of surrogate phenotypes. Cell suspensions were labeled with $\mathrm{CD} 1 \mathrm{~d} / \alpha-\mathrm{GalCer}$ tetramer and mAb specific for $3 \mathrm{G} 11, \mathrm{CD} 8$, CD24, CD62L, CD4, and $\alpha \beta$ TCR $(A)$; Ly49, CD122, and $\alpha \beta$ TCR $(B)$; NK1.1, DX5, and $\alpha \beta$ TCR $(C)$; and CD4, CD8, and $\alpha \beta$ TCR $(D)$. The first column shows the means by which the surrogate phenotypes were initially isolated (by electronic gating). The second column shows the expression of CD1d/ $\alpha$-GalCer tetramer (and NK1.1 in $C$ ) on cells with the surrogate phenotype. The third column shows the surrogate markers on NKT cells defined by CD $1 \mathrm{~d} / \alpha$-GalCer tetramer ${ }^{+} \alpha \beta \mathrm{TCR}^{+}$cells. This data are representative of samples from the thymus $(A, B$, and $D)$ or liver $(C)$ of C57BL/6 mice. Similar analysis was conducted for the other two strains (data not shown) as detailed in Table VII. 


\section{Discussion}

NKT cells have a central role in immune responses ranging from tumor rejection to the regulation of autoimmunity. Although they are believed to be present in most strains of mice, the identification of these cells in mice lacking NK1.1 expression has been difficult. A range of surrogate phenotypes has been used in an attempt to identify NKT cells in all strains of mice; however, the effectiveness of these phenotypes in isolating these cells remains uncertain. Thus, if we are to interpret studies of NKT cells in strains other than C57BL/6 with confidence, it is important to verify the status of NKT cells in these strains with reliable markers. The marker of choice for NKT cells has traditionally been the NK1.1 molecule, used in conjunction with $\alpha \beta$ TCR, CD4, and CD8 labeling. The generation of BALB/c and NOD mice congenic for the NK1.1 locus has made it possible to compare and contrast NK1.1 ${ }^{+} \mathrm{T}$ cells between these strains. NK1.1 ${ }^{+} \mathrm{T}$ cells were indeed present in each strain and, with the exception of NK1.1 ${ }^{+} \mathrm{T}$ cells in BALB.NK1.1 thymus, the levels of cell surface expression of NK1.1 and $\alpha \beta$ TCR was similar in all three strains. NK1.1 ${ }^{+} \mathrm{T}$ cells generally also had a similar tissue distribution and TCR-V $\beta$ bias (data not shown), and $\mathrm{CD} 4^{+}, \mathrm{DN}$, and $\mathrm{CD} 8^{+}$subsets of these cells were present in each strain. However, significant interstrain differences in the proportions of NK11. ${ }^{+} \mathrm{T}$ cells were observed. As was predicted based on earlier studies, NOD.NK1.1 mice had lower numbers of NKT cells in the thymus than C57BL/6 and BALB.NK1.1 mice. Unexpectedly though, BALB.NK1.1 mice also had slightly fewer thymic NKT cells than C57BL/6, and upon examination, both BALB.NK1.1 and NOD.NK1.1 mice were found to have fewer peripheral NK1.1 ${ }^{+} \mathrm{T}$ cells than C57BL/6.

The explanation for the low proportion of thymic and peripheral $\mathrm{NK} 1.1^{+} \mathrm{T}$ cells in BALB.NK1.1 mice was revealed by experiments in which these cells were colabeled with CD1d/ $\alpha$-GalCer tetramer. In contrast to C57BL/6 and NOD.NK1.1 mice, most CD1d/ $\alpha$-GalCer tetramer ${ }^{+}$NKT cells were NK1.1 ${ }^{-}$in this strain. These cells have previously been identified in C57BL/6 mice $(14,15)$, and were reported to be phenotypically similar to $\mathrm{NK} 1.1^{+} \mathrm{CD} 1 \mathrm{~d} / \alpha$ Gal-Cer tetramer ${ }^{+}$cells (i.e., V $\beta 8$ biased, CD $44^{+} \mathrm{CD} 69^{+} \mathrm{Ly}_{6 \mathrm{C}}{ }^{\text {high }}$ $\left.\mathrm{CD} 122^{+}\right)$except that a high proportion expressed CD49d $\left(\alpha_{4}\right.$ integrin) homing receptor (14). Before the development of CD1d $/ \alpha-\mathrm{Gal}-$ Cer tetramers, the possibility that NK1.1-negative NKT cells may be present in C57BL/6 mice had been suggested by several investigators. Among the NK1.1-negative $\mathrm{CD} 4^{+} \mathrm{T}$ cell population in MHC class II (I-A $\beta$-chain)-deficient mice, cells were identified that were TCR$\mathrm{V} \beta 8$ biased, and expressed the invariant $\mathrm{V} \alpha 14-\mathrm{J} \alpha 281$ chain $(24,30$, 31). Furthermore, these NK1.1-negative $\mathrm{CD} 4^{+}$T cells produced IL-4 and IFN- $\gamma$ in response to anti-CD3, $-\mathrm{CD} 1$, and $-\alpha$-GalCer treatment in vitro $(24,30)$. It was difficult to identify these cells in wild-type mice, although NK1.1-negative $\mathrm{CD} 44^{+} \mathrm{CD}_{2} 2 \mathrm{~L}^{-} \mathrm{CD} 4{ }^{+} \mathrm{T}$ cells from C57BL/6 mice were shown to produce IL-4 after anti-CD3 stimulation $(30,31)$.

The reason for the absence of NK1.1 on some NKT cells, particularly in BALB.NK1.1 mice, is not known. This may be due to the activation state of NKT cells in the BALB.NK1.1 background; in contrast to C57BL/6 and NOD.NK1.1 mice, NKT cells of BALB.NK1.1 mice (particularly those of the thymus and, to a lesser extent, the spleen) expressed lower levels of NK1.1 and higher levels of $\alpha \beta$ TCR than the other strains. When NKT cells are activated through CD3 or CD1 in vitro they have been shown to down-regulate NK1.1 on the cell surface (32). This is not related to the levels of CD1d expression, which we have found to be similar among the three strains in question (data not shown). 
A population of $\mathrm{NK} 1.1^{+} \mathrm{T}$ cells that did not bind CD1d/ $\alpha$ GalCer tetramer was also identified. These cells were more prominent in organs such as the spleen and bone marrow, and were usually highest in NOD.NK1.1 mice. They also included CD4 ${ }^{+}$, $\mathrm{DN}$, and $\mathrm{CD}^{+}$cells (data not shown). These cells probably include the CD1d-independent NK1.1 ${ }^{+} \mathrm{T}$ cells, described in detail by several researchers $(8-10)$. Unlike 'classical' NKT cells, CD1d-independent NK1.1 $1^{+} \mathrm{T}$ cells do not express a biased TCR repertoire or secrete high levels of cytokines following stimulation, and are mostly thymus independent. Some of these cells may be conventional $\mathrm{T}$ cells as virus-specific $\mathrm{T}$ cells have been observed to up-regulate NK cell markers, including NK1.1 $(33,34)$. However, an alternate possibility that should be considered is that some NK1.1 $1^{+} \mathrm{CD} 1 \mathrm{~d} / \alpha$-GalCer tetramer-negative cells could be CD1drestricted but may express a diverse TCR and/or recognize ligands other than $\alpha$-GalCer. T cell hybridomas and $\mathrm{T}$ cell clones have been produced that are reactive to CD1d but do not express the canonical V $\alpha 14-\mathrm{J} \alpha 281$ rearrangement (35-37). These $\mathrm{T}$ cell clones, which were DN or CD8 $\alpha \alpha^{+}$, produced large amounts of IFN- $\gamma$ and IL-10 following stimulation with CD1d, and were also cytotoxic against CD1d ${ }^{+}$APC (36). CD1d/ $\alpha$-GalCer tetramers did not bind CD1d-restricted $\mathrm{T}$ cell hybridomas that were $\mathrm{V} \alpha 14^{-}$(14, $15)$, prompting the suggestion that this may be due to the absence of the specific (and unknown) ligand (15). The relationship of these cells to invariant $\mathrm{V} \alpha 14-\mathrm{J} \alpha 281 \mathrm{TCR}^{+}$cells is unclear. A functional analysis of CD1d/ $\alpha$-GalCer tetramer-negative NK1.1 ${ }^{+}$ $\mathrm{T}$ cells may help determine whether these are NKT cells, although the results may be complicated if this population contains a mixture of CD1d-independent and-dependent cells.

This study has reinforced two important limitations in the use of the NK1.1 marker to identify NKT cells. One is that NK1.1 is not expressed by all CD1d-restricted NKT cells $(14,15,24)$. These cells represented the vast majority of CD1d-restricted NKT cells in BALB.NK1.1 mice, and were also a sizable population in NOD.NK1.1 mice. The other is that some NK1.1 ${ }^{+} \mathrm{T}$ cells exist that may not be NKT cells (as defined by a biased TCR expression, CD1d restriction, and high levels of cytokine production) (8-10). Several studies have used NK1.1-congenic strains (BALB/c and NOD) to identify NKT cells $(38-40)$. Our data indicate that not only may NK1.1 be an unreliable marker of these cells in some organs of C57BL/6 mice, it may be a very poor marker of these cells in other NK1.1-congenic strains. Therefore, CD1d/ $\alpha$-GalCer tetramers are probably a more reliable means of identifying NKT cells.

These results both verify and expand earlier observations $(3,5,23$, 39) that NOD mice appear to be both numerically and functionally deficient in NKT cells. More importantly, this is the first study to directly demonstrate a deficiency in peripheral NKT cells in NOD mice. Gombert et al. (3) reported that $\mathrm{Ly} 49 \mathrm{~A}^{+} \mathrm{CD} 3^{\text {int }} \mathrm{IL} 2 \mathrm{R} \beta^{+}$cells were reduced in the spleen of NOD mice compared with $\mathrm{C} 57 \mathrm{BL} / 6$; however, the meaning of this result was unclear as they also showed that this phenotype did not correlate with $\mathrm{NK} 1.1^{+} \mathrm{CD} 3^{\text {int }} \mathrm{IL} 2 \mathrm{R} \beta^{+}$ cells in C57BL/6 mice (3). Another study was published using NK1.1-congenic NOD mice, but did not provide this information (39). A very recent study by Carnaud et al. (41) described a line of NK1.1-congenic NOD mice that exhibited enhanced cytokine production (IL-4 and IFN- $\gamma$ ) by NKT cells and a reduced incidence of diabetes. In contrast, the rate and incidence of diabetes in the NOD.NK1.1 mice studied here did not differ between heterozygous congenic mice and the parental NOD/Lt strain, and thymic $\alpha \beta \mathrm{TCR}^{+} \mathrm{DN}$ NKT cells from these congenic mice produced similar levels of IL- 4 and IFN- $\gamma$ (as detected by intracellular cytokine staining) to parental NOD/Lt mice (21). Although the reasons for these differences are not clear, one possible explanation is that the Carnaud line may carry contaminating background genes that affect these phenotypes.

Very little is known about the status of $\mathrm{CD}^{+}{ }^{+}$and DN NKT cells in strains other than C57BL/6. This information is relevant as it was possible that interstrain variations in the NKT cell population were related to a particular subset. Using NK1.1 as a marker, similar proportions of each subset were present between C57BL/6 and BALB.NK1.1 mice, except for the thymus, where more NK1. $1^{+} \mathrm{T}$ cells were DN in NOD.NK1.1 and BALB.NK1.1 mice. However, when $\mathrm{CD} 1 \mathrm{~d} / \alpha$-GalCer tetramer binding cells were examined, the ratio of $\mathrm{CD}^{+}$to DN NKT cells was similar among the three strains in this tissue. The proportion of $\mathrm{CD}^{+} \mathrm{NK}^{+} .1^{+} \mathrm{T}$ cells varied among strains; however, these cells constitute a minor population that does not bind CD1d/ $\alpha$-GalCer tetramer (data not shown, and Refs. 14, 15) and are not generally considered to be NKT cells. When combined, these data indicate that both NKT cell subsets were reduced in the thymus and periphery of NOD.NK1.1 mice, whereas they are present in similar proportions in BALB.NK1.1 and C57BL/6 mice.

NKT cells from C57BL/6 and BALB.NK1.1 mice were functionally similar in terms of the level of IL-4 produced; however, these cells isolated from both the thymus and spleen of NOD.NK1.1 mice produced significantly less IL-4 than those from C57BL/6 mice after 1 day of stimulation. This finding corresponds with previous reports showing that NOD thymocytes and splenic T cells produced much lower levels of IL-4 than the same cells isolated from BALB/c mice (42). A deficiency in IL-4 production by NOD NKT cells has also been implied in previous studies. $\mathrm{CD} 24^{-} \mathrm{CD}{ }^{-}$thymocytes (enriched for NKT cells) from NOD mice produced much less IL-4 following in vitro stimulation than those from several other strains (3). Using intracellular cytokine staining, fewer DN thymocytes from NOD mice were positive for IL-4 than C57BL/ 6 after $6 \mathrm{~h}$ of stimulation (23), and IL-4 production by NOD spleen cells following anti-CD3 treatment in vivo was found to be very low (3). However, considering the differences in the frequency of NKT cells between these strains, it was important to determine whether, on a per NKT cell basis, less IL-4 was produced. The fact that by day 2 NKT cells from both the thymus and spleen of NOD.NK1.1 mice produced as much IL-4 as those from C57BL/6 suggested that this functional deficiency is limited to short-term stimulation. The other noteworthy difference was that NK1.1-negative T cells from BALB.NK1.1 mice, particularly from thymus, were capable of rapid IL-4 production. The higher frequency of $\mathrm{CD} 1 \mathrm{~d} / \alpha-\mathrm{GalCer}$ tetramer $^{+}$cells among NK1.1-negative T cells in this strain may partly explain this result. However, as these cells represent a minority of the total NK1.1negative $\mathrm{T}$ cell population, they would have to produce a larger amount than their NK1.1 $1^{+}$counterparts to account for all of the IL-4 observed. Alternatively, conventional $\mathrm{CD}^{+}{ }^{+} \mathrm{T}$ cells in BALB.NK1.1 mice may be capable of producing IL-4 after shortterm stimulation.

In summary, this is the first study to provide a detailed comparison of CD1d-restricted NKT cells (and their subsets) in three commonly used mouse strains. We also confirm that NOD mice are numerically and functionally deficient in NKT cells in most tissues when compared with $\mathrm{C} 57 \mathrm{BL} / 6$ and $\mathrm{BALB} / \mathrm{c}$ mice. Based upon our investigation of surrogate phenotypes, it seems wise to avoid using them, where possible, to represent NKT cells. Moreover, even NK1.1 can be an unreliable marker of these cells, particularly in BALB.NK1.1 mice. We suggest that CD1d/ $\alpha$-GalCer tetramers are currently the most accurate marker of invariant TCRexpressing NKT cells and offer the added advantage of identifying these cells in strains other than C57BL/6. 


\section{Acknowledgments}

We acknowledge Dr. Mitchell Kronenberg for generously providing the $\mathrm{CD} 1 \mathrm{~d} / \alpha$-GalCer tetramer and for critically reviewing the manuscript. We are also very grateful to Elise Randle-Barrett for assistance with flow cytometry and Samantha Fennell for animal husbandry assistance.

\section{References}

1. Godfrey, D. I., K. J. Hammond, L. D. Poulton, M. J. Smyth, and A. G. Baxter. 2000. NKT cells: facts, functions and fallacies. Immunol. Today 21:573.

2. Giorda, R., E. P. Weisberg, T. K. Ip, and M. Trucco. 1992. Genomic structure and strain-specific expression of the natural killer cell receptor NKR-P1. J. Immunol. 149:1957.

3. Gombert, J. M., A. Herbelin, E. Tancredebohin, M. Dy, C. Carnaud, and J. F. Bach. 1996. Early quantitative and functional deficiency of $\mathrm{NK}^{+}{ }^{+}$-like thymocytes in the NOD mouse. Eur. J. Immunol. 26:2989.

4. Bendelac, A., N. Killeen, D. R. Littman, and R. H. Schwartz. 1994. A subset of $\mathrm{CD}^{+}{ }^{+}$thymocytes selected by MHC class I molecules. Science 263:1774.

5. Baxter, A. G., S. J. Kinder, K. J. L. Hammond, R. Scollay, and D. I. Godfrey. 1997. Association between $\alpha \beta \mathrm{TCR}^{+} \mathrm{CD}^{-}{ }^{-} \mathrm{CD} 8^{-} \mathrm{T}$ cell deficiency and IDDM in NOD/Lt mice. Diabetes 46:572.

6. Falcone, M., B. Yeung, L. Tucker, E. Rodriguez, and N. Sarvetnick. 1999. A defect in interleukin 12-induced activation and interferon $\gamma$ secretion of peripheral natural killer $\mathrm{T}$ cells in nonobese diabetic mice suggests new pathogenic mechanisms for insulin-dependent diabetes mellitus. J. Exp. Med. 190:963.

7. Moodycliffe, A. M., D. Nghiem, G. Clydesdale, and S. E. Ullrich. 2000. Immune suppression and skin cancer development: regulation by NKT cells. Nat. Immunol. $1: 521$

8. Eberl, G., R. Lees, S. T. Smiley, M. Taniguchi, M. J. Grusby, and H. R. MacDonald. 1999. Tissue-specific segregation of CD1d-dependent and CD1d-independent NK T cells. J. Immunol. 162:6410.

9. Zeng, D., G. Gazit, S. Dejbakhsh-Jones, S. P. Balk, S. Snapper, M. Taniguchi, and S. Strober. 1999. Heterogeneity of NK1.1 $1^{+}$T cells in the bone marrow: divergence from the thymus. J. Immunol. 163:5338.

10. Hammond, K. J., S. B. Pelikan, N. Y. Crowe, E. Randle-Barrett, T. Nakayama, M. Taniguchi, M. J. Smyth, I. R. van Driel, R. Scollay, A. G. Baxter, and D. I. Godfrey. 1999. NKT cells are phenotypically and functionally diverse. Eur. J. Immunol. 29:3768.

11. Mendiratta, S. K., W. D. Martin, S. Hong, A. Boesteanu, S. Joyce, and L. Van Kaer. 1997. CD1d1 mutant mice are deficient in natural $\mathrm{T}$ cells that promptly produce IL-4. Immunity 6:469.

12. Smiley, S. T., M. H. Kaplan, and M. J. Grusby. 1997. Immunoglobulin E production in the absence of interleukin-4-secreting CD1-dependent cells. Science 275:977.

13. Chen, Y. H., N. M. Chiu, M. Mandal, N. Wang, and C. R. Wang. 1997. Impaired $\mathrm{NK}^{+} \mathrm{T}$ cell development and early IL-4 production in CD1-deficient mice. Immunity 6:459.

14. Benlagha, K., A. Weiss, A. Beavis, L. Teyton, and A. Bendelac. 2000. In vivo identification of glycolipid antigen-specific T cells using fluorescent CD1d tetramers. J. Exp. Med. 191:1895.

15. Matsuda, J. L., O. V. Naidenko, L. Gapin, T. Nakayama, M. Taniguchi, C. R. Wang, Y. Koezuka, and M. Kronenberg. 2000. Tracking the response of natural killer T cells to a glycolipid antigen using CD1d tetramers. J. Exp. Med. 192:741.

16. Godfrey, D. I., S. J. Kinder, P. Silvera, and A. G. Baxter. 1997. Flow cytometric study of $\mathrm{T}$ cell development in NOD mice reveals a deficiency in $\alpha$ - $\beta$ $\mathrm{TCR}^{+} \mathrm{CD} 4^{-} \mathrm{CD}^{-}$thymocytes. J. Autoimmun. 10:279.

17. Arase, H., N. Arase, K. Nakagawa, R. A. Good, and K. Onoé. 1993. $\mathrm{NK} 1.1^{+} \mathrm{CD} 4^{+} \mathrm{CD} 8-$ thymocytes with specific lymphokine secretion. Eur. J. Immunol. 23:307.

18. Hayakawa, K., B. T. Lin, and R. R. Hardy. 1992. Murine thymic CD4 ${ }^{+}$T cell subsets: a subset (Thy0) that secretes diverse cytokines and overexpresses the V $\beta 8$ T cell receptor gene family. J. Exp. Med. 176:269.

19. Vicari, A. P., and A. Zlotnik. 1996. Mouse NK1.1 $1^{+}$T cells: a new family of T cells. Immunol. Today 17:71.

20. Scalzo, A. A., P. A. Lyons, N. A. Fitzgerald, C. A. Forbes, and G. R. Shellam. 1995. The BALB.B6-Cmv1r mouse: a strain congenic for Cmv1 and the NK gene complex. Immunogenetics 41:148.
21. Poulton, L. D., M. J. Smyth, C. Hawke, P. Silvera, D. Shepherd, D. I. Godfrey, and A. G. Baxter. 2001. Cytometric and functional analyses of NK and NKT cell deficiencies in NOD mice. Int. Immunol. 13:101.

22. Ryan, J. C., J. Turck, E. C. Niemi, W. M. Yokoyama, and W. E. Seaman. 1992. Molecular cloning of the NK1.1 antigen, a member of the NKR-P1 family of natural killer cell activation molecules. J. Immunol. 149:1631.

23. Hammond, K. J. L., L. D. Poulton, L. J. Palmisano, P. A. Silveira, D. I. Godfrey, and A. G. Baxter. 1998. $\alpha / \beta$-T cell receptor (TCR) ${ }^{+} \mathrm{CD}^{-} \mathrm{CD}^{-}$(NKT) thymocytes prevent insulin-dependent diabetes mellitus in nonobese diabetic (NOD)/Lt mice by the influence of interleukin (IL)-4 and/or IL-10. J. Exp. Med. 187:1047.

24. Hameg, A., I. Apostolou, M. Leite-De-Moraes, J. M. Gombert, C. Garcia, Y. Koezuka, J. F. Bach, and A. Herbelin. 2000. A subset of NKT cells that lacks the NK1.1 marker, expresses CD1d molecules, and autopresents the $\alpha$-galactosylceramide antigen. J. Immunol. 165:4917.

25. Moore, T. A., U. vonFreeden-Jeffry, R. Murray, and A. Zlotnik. 1996. Inhibition of $\gamma \delta \mathrm{T}$ cell development and early thymocyte maturation in $\mathrm{IL} 7^{-1-}$ mice. J. Immunol. 157:2366.

26. Ortaldo, J. R., R. Winkler-Pickett, A. T. Mason, and L. H. Mason. 1998. The Ly-49 family: regulation of cytotoxicity and cytokine production in murine $\mathrm{CD}^{+}$cells. J. Immunol. 160:1158.

27. Leite de Moraes, M. D., G. Moreau, A. Arnould, F. Machavoine, C. Garcia, M. Papiernik, and M. Dy. 1998. IL-4-producing NKT cells are biased toward IFN- $\gamma$ production by IL-12: influence of the microenvironment on the functional capacities of NK T cells. Eur. J. Immunol. 28:1507.

28. Kennedy, J., A. P. Vicari, V. Saylor, S. M. Zurawski, N. G. Copeland, D. J. Gilbert, N. A. Jenkins, and A. Zlotnik. 2000. A molecular analysis of NKT cells: identification of a class-I restricted T cell-associated molecule (CRTAM). J. Leukocyte Biol. 67:725.

29. Coles, M. C., and D. H. Raulet. 1994. Class I dependence of the development of $\mathrm{CD}^{+} \mathrm{CD} 8{ }^{-} \mathrm{NK}^{+} .1^{+}$thymocytes. J. Exp. Med. 180:395.

30. Chen, H., and W. E. Paul. 1998. A population of CD62L ${ }^{\text {low }} \mathrm{NK} 1.1^{-} \mathrm{CD}^{+} \mathrm{T}$ cells that resembles NK1.1 ${ }^{+} \mathrm{CD} 4^{+}$T cells. Eur. J. Immunol. 28:3172.

31. Hameg, A., C. Gouarin, J. M. Gombert, S. Hong, L. Van Kaer, J. F. Bach, and A. Herbelin. 1999. IL-7 up-regulates IL-4 production by splenic NK1.1 ${ }^{+}$and NK1.1 ${ }^{-}$MHC class I-like/CD1-dependent CD4 ${ }^{+}$T cells. J. Immunol. 162:7067.

32. Chen, H. J., H. Huang, and W. E. Paul. 1997. NK1.1 ${ }^{+}$CD $4^{+}$T cells lose NK1.1 expression upon in vitro activation. J. Immunol. 158:5112.

33. Kambayashi, T., E. Assarsson, J. Michaelsson, P. Berglund, A. D. Diehl, B. J. Chambers, and H. G. Ljunggren. 2000. Emergence of CD8 ${ }^{+}$T cells expressing NK cell receptors in influenza A virus-infected mice. J. Immunol. 165: 4964.

34. Slifka, M. K., R. R. Pagarigan, and J. L. Whitton. 2000. NK markers are expressed on a high percentage of virus-specific $\mathrm{CD} 8^{+}$and $\mathrm{CD}^{+} \mathrm{T}$ cells. J. Immunol. 164:2009.

35. Cardell, S., S. Tangri, S. Chan, M. Kronenberg, C. Benoist, and D. Mathis. 1995. $\mathrm{CD} 1$-restricted $\mathrm{CD}^{+} \mathrm{T}$ cells in major histocompatibility complex class II-deficient mice. J. Exp. Med. 182:993.

36. Behar, S. M., T. A. Podrebarac, C. J. Roy, C. R. Wang, and M. B. Brenner. 1999. Diverse TCRs recognize murine CD1. J. Immunol. 162:161.

37. Chiu, Y. H., J. Jayawardena, A. Weiss, D. Lee, S. H. Park, A. Dautry-Varsat, and A. Bendelac. 1999. Distinct subsets of CD1d-restricted T cells recognize selfantigens loaded in different cellular compartments. J. Exp. Med. 189:103.

38. von der Weid, T., A. M. Beebe, D. C. Roopenian, and R. L. Coffman. 1996. Early production of IL-4 and induction of Th2 responses in the lymph node originate from an MHC class I-independent CD $4^{+} \mathrm{NK} 1.1^{-}$T cell population. J. Immunol. 157:4421.

39. Lehuen, A., O. Lantz, L. Beaudoin, V. Laloux, C. Carnaud, A. Bendelac, J. F. Bach, and R. C. Monteiro. 1998. Overexpression of natural killer T cells protects $\mathrm{V} \alpha 14-\mathrm{J} \alpha 281$ transgenic nonobese diabetic mice against diabetes. J. Exp. Med. 188:1831.

40. Terabe, M., S. Matsui, N. Noben-Trauth, H. Chen, C. Watson, D. D. Donaldson, D. P. Carbone, W. E. Paul, and J. A. Berzofsky. 2000. NKT cell-mediated repression of tumor immunosurveillance by IL-13 and the IL-4R-STAT6 pathway. Nat. Immunol. 1:515.

41. Carnaud, C., J. Gombert, O. Donnars, H. Garchon, and A. Herbelin. 2001. Protection against diabetes and improved NK/NKT cell performance in NOD.NK1.1 mice congenic at the NK complex. J. Immunol. 166:2404.

42. Rapoport, M. J., A. Jaramillo, D. Zipris, A. H. Lazarus, D. V. Serreze, E. H. Leiter, P. Cyopick, J. S. Danska, and T. L. Delovitch. 1993. Interleukin-4 reverses T-cell proliferative unresponsiveness and prevents the onset of diabetes in nonobese diabetic mice. J. Exp. Med. 178:87. 